\title{
Benthic biogeochemistry: State of the art technologies and guidelines for the future of in situ survey
}

Article in Journal of Experimental Marine Biology and Ecology · February 2003

DOI: 10.1016/S0022-0981(02)00517-8

\section{CITATIONS}

120

18 authors, including:

Eric Viollier

Paris University

153 PUBLICATIONS 3,234 CITATIONS

SEE PROFILE

\section{Sabine E Apitz}

SEA Environmental Decisions Ltd

128 PUBLICATIONS 2,889 CITATIONS

SEE PROFILE
READS

269

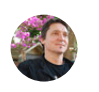

Christophe Rabouille

Laboratoire des Sciences du Climat et l'Environnement 184 PUBLICATIONS 3,635 CITATIONS

SEE PROFILE

Eric R. Breuer

National Oceanic and Atmospheric Administration 20 PUBLICATIONS 496 CITATIONS

SEE PROFILE

Some of the authors of this publication are also working on these related projects:

Effect of a natural Baltic oxygenation-deoxygenation cycle on benthic recycling of P, N, Si and C - An in situ observation View project

AMORAD- Improvement of radionuclides dispersion and impact assessment modelling in the environment. View project 


\title{
Benthic biogeochemistry: state of the art technologies and guidelines for the future of in situ survey
}

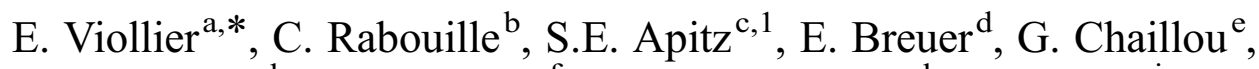

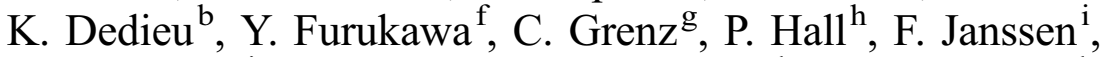
J.L. Morford ${ }^{\mathrm{j}}$, J.-C. Poggiale ${ }^{\mathrm{g}}$, S. Roberts ${ }^{\mathrm{k}}$, T. Shimmield ${ }^{\mathrm{d}}$, M. Taillefert ${ }^{1}$, A. Tengberg ${ }^{\mathrm{h}}$, F. Wenzhöfer ${ }^{\mathrm{m}}, \mathrm{U}$. Witte ${ }^{\mathrm{i}}$

${ }^{a}$ Laboratoire de Géochimie des Eaux, UMR Physico-Chimie des Fluides Geologiques, Université Denis Diderot-Paris 7 and IPGP, Case Postale 7052, 75251 Paris cedex 05, France

${ }^{\mathrm{b}}$ Laboratoire des Sciences du Climat et de l'Environnement, CEA-CNRS, 91191 Gif/Yvette, France

${ }^{\mathrm{c}}$ Sediment Management Laboratory, SSC San Diego D361, Environmental Sciences Division, 53475 Strothe Road, San Diego, CA 92152-6325, USA

${ }^{\mathrm{d}}$ SAMS, Dunstaffnage Marine Laboratory, Oban, PA34 4AD, UK

${ }^{\mathrm{e}}$ Université Bordeaux 1, DGO, UMR CNRS 5805, Av. des Facultés, 33405 Talence cedex, France

${ }^{\mathrm{f}}$ Naval Research Laboratory, Seafloor Sciences Branch, Stennis Space Center, MS 39529, USA

${ }^{\mathrm{g}}$ Laboratoire d'Océanologie et de Biogéochimie, UMR CNRS 6535, Campus de Luminy, 13009 Marseille, France

${ }^{\mathrm{h}}$ Department of Analytical and Marine Chemistry, Goteborg University, SE-412 96 Goteborg, Sweden

${ }^{\mathrm{i}}$ Max Planck Institut for Marine Microbiology, Celsiusstr. 1, 28359 Bremen, Germany

${ }^{\mathrm{j}}$ Department of Marine Chemistry and Geochemistry, Woods Hole Oceanographic Institution, MS \#25, Woods Hole, MA 02543, USA

${ }^{\mathrm{k}}$ School of Biological Sciences, Monash University, Clayton, Victoria 3800, Australia

${ }^{1}$ Georgia Institute of Technology, School of Earth and Atmospheric Sciences, 221 Bobby Dodd Way, Atlanta, GA 30332-0340, USA

${ }^{\mathrm{m}}$ Marine Biological Laboratory, University of Copenhagen, Strandpromenaden 5, 3000 Helsingør, Denmark

Received 12 September 2002; received in revised form 25 October 2002; accepted 31 October 2002

\begin{abstract}
Sediment and water can potentially be altered, chemically, physically and biologically as they are sampled at the seafloor, brought to the surface, processed and analysed. As a result, in situ observations of relatively undisturbed systems have become the goal of a growing body of scientists.
\end{abstract}

* Corresponding author. Tel.: +33-144-276036; fax: +33-144-276038.

E-mail address: viollier@ipgp.jussieu.fr (E. Viollier).

${ }^{1}$ Currently at South Cottages, The Ford, Little Hadham, Hertfordshire SG11 2AT, UK. 
Our understanding of sediment biogeochemistry and exchange fluxes was revolutionized by the introduction of benthic chambers and in situ micro-electrode profilers that allow for the direct measurement of chemical fluxes between sediment and water at the sea floor and for porewater composition. Since then, rapid progress in the technology of in situ sensors and benthic chambers (such as the introduction of gel probes, voltammetric electrodes or one- and two-dimensional optodes) have yielded major breakthroughs in the scientific understanding of benthic biogeochemistry. This paper is a synthesis of discussions held during the workshop on sediment biogeochemistry at the "Benthic Dynamics: in situ surveillance of the sediment-water interface" international conference (Aberdeen, UK-March 25-29, 2002). We present a review of existing in situ technologies for the study of benthic biogeochemistry dynamics and related scientific applications. Limitations and possible improvement (e.g., technology coupling) of these technologies and future development of new sensors are discussed. There are countless important scientific and technical issues that lend themselves to investigation using in situ benthic biogeochemical assessment. While the increasing availability of these tools will lead research in yet unanticipated directions, a few emerging issues include greater insight into the controls on organic matter (OM) mineralization, better models for the understanding of benthic fluxes to reconcile microelectrode and larger-scale chamber measurements, insight into the impacts of redox changes on trace metal behavior, new insights into geochemical reaction pathways in surface sediments, and a better understanding of contaminant fate in nearshore sediments.

(C) 2002 Elsevier Science B.V. All rights reserved.

Keywords: Sediment; Biogeochemistry; In situ technologies; Microelectrodes; Benthic chambers; Optodes; Gel peepers

\section{Introduction}

The development of in situ technologies during the last 20 years has resulted in rapid progress in oceanographic research. During the 1970 s and before, most chemical measurements were realized on board ship or in the laboratory, using conventional chemical procedures. The sampling was conducted with bottle samplers or sediment corers, and retrieved samples were subsequently processed on deck. However, sediment and porewaters can be significantly altered, chemically, physically and biologically, as they are sampled at the seafloor, brought to the surface, processed and analysed. As a result, in situ observations of relatively undisturbed systems have become the goal of a growing body of scientists. Our understanding of sediment biogeochemistry and exchange fluxes was revolutionized by the introduction of benthic chambers and in situ microelectrode profilers. Indeed, in situ benthic flux chamber incubations have provided an effective means to quantify the mass transfer rate across the sediment-water interface and in situ high-resolution microprofiles offered a way to determine pore water solute concentration, allowing rates of metabolic and chemical processes within the sediment to be accurately quantified with the help of transport-reaction models. At the same time, the first sediment traps were deployed to determine vertical particle fluxes in the water column and more recently, in situ analysers allow nutrient measurements to be taken within the water column. Rapid progress in the technology of in situ sensors means that they are now effective at sub-millimeter scales. Benthic chamber designs as well as the 
introduction of gel probes and planar optodes have also yielded major breakthroughs in the scientific understanding of benthic biogeochemistry.

This paper is a synthesis of discussions held during the workshop on sediment biogeochemistry at the "Benthic Dynamics: in situ surveillance of the sediment-water interface" international conference (Aberdeen, UK-March 25-29, 2002). In particular, this workshop sought to evaluate the current state of in situ benthic technologies that allow for the assessment of sediment reactivity through porewater chemical signatures, as well as the direct determination of fluxes, on small temporal and spatial scales. In this paper, we present a non-exhaustive review of existing micro-sensors technologies for the study of benthic biogeochemistry and their already finalized or potential in situ applications. We also report on some of the scientific and technological issues that will undergo future developments, required to further improve our understanding of benthic biogeochemical dynamics in marine and freshwater settings.

\section{Existing technologies and scientific achievements}

This section reviews the in situ technologies which are currently available and their historical development: (1) benthic chambers which are designed to determine solute fluxes through the sediment-water interface, (2) electrochemical sensors, (3) optical sensors and (4) methods which are designed to achieve relatively high resolution in situ porewater sampling. Major scientific findings are also briefly reported.

\subsection{Benthic chambers}

Benthic chambers (also called boxes, bell jars, micro/mesocosms, etc.) have been used since the mid-1960s to study rates of benthic respiration and sediment-water solute exchange in situ. A benthic chamber is a device that is placed on the sediment, enclosing a known area of the sediment surface together with a known volume of ambient overlying bottom water. Measurements of solute concentrations in the overlying water are mostly performed using distinct water samples. In order to achieve continuous measurements at the surface of impermeable sediments, benthic chambers have also been equipped with different sensors, such as $\mathrm{O}_{2}$ electrodes and optodes (Glud et al., 1994a,b, 1999a; Tengberg et al., 1995), $\mathrm{pH}$, and $\mathrm{H}_{2} \mathrm{~S}$ electrodes (Stueben et al., 1998). Concentration changes in the enclosed overlying water over time are used to calculate fluxes of solutes into or out of the sediment. These flux calculations are based on four assumptions: (1) steady state conditions are valid during the in situ incubation period with respect to solute exchange (i.e., with respect to concentration gradients within the sediment and between the sediment and the overlying water); (2) the rates of biogeochemical processes in the overlying water column are negligible compared to those within the sediment unless measured separately and taken into account in the final flux calculation; (3) the hydrodynamic regime inside the chamber does not alter solute exchange across the sedimentwater interface as compared to natural conditions; and (4) the size of the sampling/ measurements area is representative for a larger seafloor area. Under various circumstances, either one or more of these assumptions may not be true. While this does not 
preclude the use of chambers to estimate fluxes, these assumptions, and the degree to which a site may or may not conform to them, must be kept in mind during data analysis and interpretation. These methods have been utilised for a range of analytes, including inorganic constituents such as oxygen and nutrients (McCaffrey et al., 1980; Berelson et al., 1990; Jahnke, 1990), natural and anthropogenic trace metals (Ciceri et al., 1992; Chadwick et al., 1994; Leather et al., 1995), and are currently being adapted for organic contaminants (Chadwick, pers. comm.).

In shallow water, benthic chamber deployments, sampling and sediment recovery can be performed by Scuba divers (e.g., Hallberg et al., 1972; Nixon et al., 1976; Hammond et al., 1977; Balzer 1978). Autonomous chamber incubations have been conducted since the end of the 1970s, extending the investigation of benthic activity and fluxes down to the abyssal plains. Smith (1978) carried out pioneering work by measuring the sediment community oxygen consumption (SCOC, also called total oxygen uptake, TOU) down to abyssal water depths with a chamber mounted on a free-falling vehicle. Now, modular benthic landers equipped with several chambers that allow simultaneous replicate measurements are almost routinely performed in deep-sea research (e.g., Witbaard et al., 2000; Witte and Pfannkuche, 2000; Ståhl et al., in press (a,b)). Tengberg et al. (1995) wrote an overview of the history and technical evolution of chamber and profiling lander designs (e.g., to limit landing disturbance of the sediment-water interface), though the subsequent years have led to new developments.

Much effort has focused on the construction of an 'ideal' chamber and on the characterization of chambers in use with respect to hydrodynamic regime, diffusive boundary layer (DBL) thickness as well as pressure and shear stress distribution (e.g., Santschi et al., 1983; Opdyke et al., 1987; Buchholtztenbrink et al., 1989; Glud et al., 1995; Tengberg et al., submitted for publication (a)). The general consensus is that due to the low biogeochemical activity of abyssal sediments, DBL resistance on exchange rates of oxygen can often be neglected in the deep-sea (Jørgensen and Boudreau, 2001; Reimers, et al., 2001). In active coastal sediments with high oxygen uptake rates, however, hydrodynamic effects and DBL impedance can be of importance, and the effects of the imposed DBL must be evaluated (e.g., Jørgensen and Revsbech, 1985; Hall et al., 1989; Jørgensen and Des Marais, 1990; Jørgensen and Boudreau, 2001). One intercalibration between the many different chamber designs is under progress as part of the ALIPOR project (Tengberg et al., submitted for publication (a)). In one of the experiments involving several replicates of three different chamber designs, no significant effect of chamber hydrodynamics or design on oxygen and nutrient fluxes measured on a homogenized, macrofauna-free sediment could be detected. Also, total oxygen fluxes measured in the chambers were almost identical to diffusive oxygen fluxes calculated from porewater oxygen microprofiles. In the other intercalibration experiment, involving 16 different chamber designs, significant differences between fluxes measured on homogenized, macrofauna-free sediments were found for some of the chambers. The only variable showing a significant correlation with the measured fluxes to so far have been identified is water column height in the chambers. However, the statistical evaluation of this huge data set is still in progress. A computer simulation producing a virtual seafloor with natural fauna abundance and heterogeneity recently focused on the effects of chamber size and number of deployments on retrieved benthic oxygen uptake rates. This tool allows one to quantify to what extent a 
given measurement (or number of measurements) represent the actual exchange rate at the seafloor. Output results showed that large chambers and multiple deployments are to be preferred to get an adequate picture of the total oxygen consumption especially at sites with high macrofauna abundance (Glud and Blackburn, 2002).

Historically, the main focus of chamber work has been the examination of benthic $\mathrm{O}_{2}$ uptake as the most reliable measure of total benthic carbon degradation in sediments, at least in the deep sea, where sediments are exposed to well-oxygenated bottom water. In coastal and shelf sediments with a significant contribution of anoxic mineralization (i.e., extremely oxygen depleted or anoxic environments), dissolved inorganic carbon fluxes have been found to be a better measure of total benthic organic carbon degradation (Anderson et al., 1986; Hall et al., 1990; Thamdrup and Canfield, 2000) even though calcium carbonate dissolution may supply a significant amount of carbonate and prevent accurate assessment of organic carbon mineralization rates. However, calcium carbonate dissolution can be compensated for by measuring $\mathrm{Ca}^{2+}$ (Anderson et al., 1986) or alkalinity (e.g., Ståhl et al., in press (a)) fluxes and DIC fluxes simultaneously. Numerous chamber deployments, ranging from shallow waters down to abyssal depths, have provided insight into the contribution of sediments to the remineralization of organic matter on a global scale (e.g., Smith, 1978; Smith and Baldwin, 1984; Jahnke, 1996; Smith et al., 1997; Smith and Kaufmann, 1999; Wenzhöfer and Glud, 2002). In some cases, there is a good agreement between general spatial patterns of primary productivity and the sediment community oxygen consumption (SCOC), but in other studies vertical POC fluxes as derived from sediment traps are not sufficient to fuel benthic remineralization rates. This may have been caused by an insufficient temporal resolution of the sediment trap measurements, but has also been taken as evidence for the existence of lateral input of organic matter (Smith and Baldwin, 1984; Rowe et al., 1994). Whether temporal variations in surface water productivity are mirrored in temporal changes in SCOC is still unclear. There are as many arguments in favour of this hypothesis as against it (e.g., Smith and Baldwin, 1984; Smith et al., 1992; Pfannkuche, 1993; Drazen et al., 1998; Sayles et al., 1994; Witbaard et al., 2000; Witte and Pfannkuche, 2000; Ståhl et al., in press (a)). It may also be possible that seasonal variability of SCOC exists in one ocean basin but not in another, for reasons that are not yet clear. Concerning the structure of benthic food webs and the rates and pathways of carbon cycling, recent technological advances have permitted new experimental approaches (Smith et al., 2001). For example, in situ organic matter pulse chase experiments with chambers modified for the injection of particulate tracers can provide new insights into these scientific issues in continental slope (Moodley et al., 2002; Witte et al., in press) and deep-sea locations.

In permeable shelf sediments, advective porewater exchange due to horizontal pressure gradients at the sediment surface can significantly enhance the total solute exchange across the sediment-water interface (Huettel and Gust 1992a,b; Huettel et al., 1996). In most benthic chambers, the driving forces of these horizontal pressure gradients (i.e., interaction of water flow and sediment topography, gravity waves) are cut-off. However, it has been demonstrated that cylindrical benthic chambers, with stirring-induced radial pressure gradients as a substitute for natural pressure gradients, can be used as model systems to study advection effects (Glud et al., 1996b; Huettel and Rusch, 2000). The effect of waveinduced transport in permeable sediments can also be studied using chambers with flexible 
walls that allow pressure variations to propagate into the chamber (Malan and Mc Lachlan, 1991). Chambers that mimic advective flushing and chambers with flexible walls produced evidence that advective processes strongly enhance remineralization rates in coarse shelf sediments (Malan and Mc Lachlan, 1991).

A variety of chamber designs have been used to create sediment resuspension events mainly focusing on factors controlling the erosion and sediment transport process itself (Black and Paterson, 1997; Black et al., submitted for publication). Similar devices also offer the opportunity to investigate the consequences of resuspension events on carbon recycling and nutrient release (e.g., Tengberg et al., 2003, this volume). Other manipulation of the chamber environment such as maintaining the oxygen concentration at an ambient level, may also be of interest in the study of chemical species sensitive to oxygen (metals, trace contaminants, reduced chemical species). Technical solutions to compensate for the loss of oxygen inside chambers are mostly based upon a gas permeable membrane or tubing which is in contact with overlying water while the opposing surface is flushed by either gaseous oxygen, ambient water or oxygen enriched water (Hall, 1984; Rutgers van der Loeff et al., 1984; Hall et al., 1989; Ciceri et al., 1992; Chadwick et al., 1993; Rowe et al., 1994). Linking such systems with oxygen sensors allow for strict control of oxygen levels.

The above summary makes it clear that there are countless choices that can be made in benthic chamber design, to address specific research questions or to make chambers more "realistic". However, it is also clear that all design choices cannot be applied to a single chamber, and that chamber design parameters such as oxygen control, size, replication, flexibility, etc., should be carefully tailored to the study site and goals, and in each case landing speed, carefully controlled (Tengberg et al., submitted for publication (b)).

\subsection{Electrochemical in situ microsensors}

The highest biogeochemical activity in sediments occurs close to the sediment-water interface (often within millimeters). This narrow spatial scale is extremely susceptible to sample perturbation during collection of a sediment core. In situ measurements made with electrochemical microsensors minimize sediment-water interface distortions (mixing), leaving natural gradients of metabolites and substrates intact and allowing for submillimeter scale resolution. Additionally, data acquisition can be rapid, providing quantitative information in real- or near-real-time, which can, in turn, guide subsequent sampling and analysis. This approach increases the probability of obtaining meaningful results. However, because samples are analyzed directly, without any sample preparation (such as separation or purification, which are often done in the laboratory), analyses may be subject to uncontrollable matrix interferences, lack of specificity or selectivity, problems of reversibility, fouling and drift. The effect and extent of these issues are dependent upon the specific method, analyte and environment, but these issues must be kept in mind. A wide range of electrochemical microsensors has so far been developed for aquatic environmental research including conductimetry to measure salinity; amperometric and potentiometric sensors that can measure a single analyte; and voltammetric sensors that can measure several species simultaneously. It is, however, beyond the scope of this paper to describe and discuss all available sensors in detail. Instead, we present a brief overview of the most relevant microsensors used in in situ biogeochemistry. Reviews on 
the development and application of microsensors can be found elsewhere in the literature (e.g., Taillefert and Luther, 2000; Kühl and Revsbech, 2001; Buffle and Horvai, 2000; Taillefert and Rozan, 2002).

Amperometric electrodes measure reduction current at a single potential, potentiometric electrodes measures the difference of potential between the solution and the electrode and voltammetric sensors use a scanning of potential and measure reduction currents to operate a multi-elemental analysis.

In amperometry, the current is measured at an auxiliary electrode when a constant potential is applied between a reference electrode, usually silver/silver chloride, and the indicator electrode. The most common amperometric sensor is the oxygen, or Clark, electrode (Gnaiger and Forstner, 1983). The introduction of "Clark-type" amperometric oxygen microelectrodes has provided a powerful and reliable electrochemical tool to gain insight into chemical and biological reactions processes of carbon and oxygen within the marine environment. (Jørgensen, 1977; Revsbech et al., 1980; Helder and Bakker, 1985; Glud et al., 2000). These sensors have been routinely deployed to measure concentrations of oxygen in sediments and overlying waters at sub-millimeter scales (e.g., Revsbech et al., 1983; Reimers et al., 1986; Revsbech and Jorgensen, 1986a,b; Visscher et al., 1991; Gundersen and Jorgensen, 1990; Cai and Reimers, 1993; Glud et al., 1994a,b; Tenberg et al., 1995; Wenzhöfer and Glud, 2002). These profiles performed within millimeters of the sedimentwater interface where high levels of labile organic matter are subject to rapid and extensive diagenetic reactions have allowed to quantify diffusive fluxes into or out of sediments and to provide depth zonation of key biogeochemical reactions (e.g., organic matter mineralization, oxidation of reduced chemical compounds). The comparison of diffusive oxygen uptake (DOU) calculated from porewater profiles with benthic chamber total oxygen uptake (TOU) has also largely illustrated the role of infauna in solute transfer through the sediment-water interface from the coastal ocean to abyssal environments (Archer and Devol, 1992; Glud et al., 1994a; Hulth et al., 1994). Wenzhöfer and Glud (2002) showed that the ratio between total and diffusive fluxes varies in relation to macrofaunal irrigation activities, from 3-4 on the upper continental slope to almost 1 in oligotrophic regions. However, in some shallow systems, comparisons of DOU with TOU showed similar results, suggesting that, in some cases, oxygen fluxes may be specifically driven by microbial activity rather than bioirrigation (Grenz et al., this volume; Rabouille et al., 2003).

A number of sensors have also potential for in situ application: an amperometric sensor has been built to detect $\mathrm{N}_{2} \mathrm{O}$ in biofilms (Revsbech et al., 1988). An amperometric microsensor to measure $\mathrm{H}_{2} \mathrm{~S}$ (Jerochewski and Braun, 1996; Kühl et al., 1998) has also been used to study the microenvironment of a coastal sediment in situ (Wenzhöfer et al., 2000). In contrast to potentiometric $\mathrm{Ag} / \mathrm{Ag}_{2} \mathrm{~S}$ sensors, the $\mathrm{H}_{2} \mathrm{~S}$ microelectrode is insensitive to oxygen and are therefore easier to handle. Recently, bioelectrochemical sensors have been developed to measure $\mathrm{NO}_{3}^{-}$in marine sediments (Larsen et al., 1997) and $\mathrm{CH}_{4}$ in sediments and biofilms (Damgaard and Revsbech, 1997). The $\mathrm{NO}_{3}^{-}$biosensor contains a microbial community that reduces $\mathrm{NO}_{3}^{-}$and $\mathrm{NO}_{2}^{-}$to $\mathrm{N}_{2} \mathrm{O}$ before measurement with a $\mathrm{N}_{2} \mathrm{O}$ electrode (Revsbech et al., 1988; Meyer et al., 2001). The $\mathrm{CH}_{4}$ biosensor contains aerobic methane oxidizers that consume $\mathrm{O}_{2}$; the decrease in $\mathrm{O}_{2}$ is then measured by a Clark electrode (Revsbech et al., 1983). It is, however, yet not possible to appraise wether these sensors can be used in situ or not. 
Other types of electrodes combination based on potentiometry are used to measure a large array of dissolved compounds. In potentiometry, the difference of potential between a reference electrode and an indicator electrode is measured with a high impedance voltmeter in the absence of appreciable currents. The boundary potential, or the difference in potential between the external and the internal solution at the indicator electrode, is sensitive to the activity of ions according to the Nernst equation. Potentiometric microsensors commonly used in sedimentary environments include membrane electrodes to determine the $\mathrm{pH}$ or $\mathrm{S}_{2}^{-}$(Cai and Reimers, 1993; Revsbech et al., 1983), molecular electrodes to determine $p \mathrm{CO}_{2}$ (Revsbech et al., 1983; De Beer et al., 1997a,b; Zhao and Cai, 1997), and ion selective electrodes (ISEs) to determine $\mathrm{NO}_{3}^{-}, \mathrm{NO}_{2}^{-}, \mathrm{NH}_{4}^{+}, \mathrm{Ca}^{2+}$, $\mathrm{CO}_{3}^{2-}$ (Müller et al., 1998; DeBeer et al., 1997a,b). The combined use of benthic chambers estimating alkalinity and $\mathrm{Ca}^{2+}$ fluxes and in situ microelectrodes measuring $\mathrm{pH}$ and $p \mathrm{CO}_{2}$ has resulted in major breakthroughs in the study of carbonate dissolution in deep sea sediment (Archer et al., 1989; Berelson et al., 1990; Cai and Reimers, 1993; Jahnke et al., 1994; Cai et al., 1995; Hales and Emerson, 1996; Wenzhöfer et al., 2001b). Using these techniques, it has been shown that organic matter has a pronounced influence on carbonate dissolution in deep-sea sediments by producing metabolic carbonic acid, which promotes dissolution of calcite above the ocean lysocline. These authors also showed that carbonate dissolution rates are very different in situ than in the laboratory, which makes the use of in situ assessments even more critical for the quantification of carbonate dynamics at the sea-floor.

Other in situ electrochemical measurements have been conducted in biofilms, where the distribution of dissolved sulfide has been shown to overlap with oxygen on a dial cycle (Visscher et al., 1991), and in stromatolites where the decoupling of sulfide oxidation and sulfate reduction may result in the formation of micritic $\mathrm{CaCO}_{3}$ precipitates (Visscher et al., 2002). Recently, in situ measurements using an amperometric sensor have revealed that sulfide may be produced in lake sediments and that sulfate reduction accounts for a significant fraction of organic carbon mineralization (Kühl et al., 1998).

In voltammetry, the potential is ramped between a working electrode and a reference electrode. At an appropriate potential, an analyte is oxidized or reduced at the working electrode and the current resulting from this reaction is measured at an auxiliary electrode. Voltammetric techniques are attractive for the measurement of chemical species in sediment porewaters because they can detect several analytes in the same potential scan, they have low detection limits $(\mu \mathrm{M})$, and they generally do not suffer from matrix problems (e.g., high salinity) (Florence, 1986). Voltammetry in sedimentary environments is mostly used with mercury electrodes, because their analytical window is ideal for the direct measurements of $\mathrm{O}_{2(\text { aq) }}, \mathrm{NH}_{2} \mathrm{~S}$ (i.e., $\mathrm{H}_{2} \mathrm{~S}+\mathrm{HS}^{-}, \mathrm{S}^{2-}$, and $\mathrm{S}(0)$ in $\mathrm{S} 8$ and $\mathrm{S}_{x}^{2-}$ ), $\mathrm{Fe}^{2+}, \mathrm{Mn}^{2+}, \mathrm{S}_{2} \mathrm{O}_{3}^{2-}, \mathrm{S}_{4} \mathrm{O}_{6}^{2-}$, and $\mathrm{I}^{-}$, as well as the detection of aqeous clusters of $\mathrm{FeS}$ (Theberge and Luther, 1997) and soluble organic complexes of $\mathrm{Fe}^{3+}$ (Taillefert et al., 2000). Trace metals may also be measured by these techniques, and some measurements have been reported in contaminated sediments (Nolan and Gaillard, 2002). However, the development of microelectrodes to determine low concentrations of trace metals in sediment porewaters is still in its infancy (Tercier-Waeber et al., 2000).

Voltammetric microelectrodes have been combined in situ with Clark and $\mathrm{pH}$ microelectrodes (Luther et al., 1999) to assess the cycling of $\mathrm{Mn}^{2+}$ and $\mathrm{Fe}^{2+}$ in continental shelf 
sediments. It evidenced that $\mathrm{pH}$ variations occur according to the diagenetic sequence of natural organic matter mineralization and that $\mathrm{Mn}^{2+}$ is eventually removed by adsorption onto authigenic phases or precipitation of carbonate minerals. In addition, voltammetric measurements coupled to porewater microprofiles have evidenced unknown biogeochemical processes: interactions between nitrogen and metal cycles (oxidation of ammonium by metal oxides, anaerobic reduction of nitrate by reduced iron or manganese) and interactions between sulfur and iron cycle linked to the speciation of iron or sulfur species have been inferred (Brendel and Luther, 1995; Luther et al., 1997, 2001; Xu et al., 1997; Rickard et al., 1999; Taillefert et al., 2000, 2002; Bull and Taillefert, 2001; Glazer et al., 2002).

\subsection{Optical micro-sensors}

Optical microsensors, also called micro-optodes, have recently been introduced into the field of aquatic ecology (Klimant et al., 1995). Most applications and developments, however, have been made in other disciplines such as analytical chemistry and biomedical research (e.g., Wolfbeis, 1991, 2000; Wolfbeis et al., 1998). There are optical sensors available for $\mathrm{O}_{2}$ (Klimant et al., 1995, 1997a; Wenzhöfer et al., 2001a), temperature (Holst et al., 1997a; Klimant et al., 1997a), pH (Kohls et al., 1997), nitrate (Huber et al., 2001a), $p \mathrm{CO}_{2}$ (Hales et al., 1997; Holst et al., 2000; Neurauter et al., 2000; Wenzhöfer et al., 2001b), salinity (Huber et al., 2000), chloride which can be used as a proxy for salinity in seawater (Huber et al., 2001b), surface detection (Klimant et al., 1997b), irradiance (Lassen et al., 1992; Kühl et al., 1994, 1997) and flow (DeBeer, 1997). It is beyond the scope of this section to describe all existing optical microsensors. However, reviews of optical sensors and measuring systems as well as their applications can be found elsewhere (Klimant et al., 1997b; Glud et al., 2000; Holst et al., 2000; Kühl and Revsbech, 2001; Holst and Mizaikoff, 2002). Here we present a brief overview of oxygen optodes and their use/advantage in biogeochemical analysis of carbon mineralization and other processes in marine sediments.

Planar optodes-the fundamental principle behind measuring oxygen concentrations with optodes is based on the dynamic quenching of a luminophore in the presence of oxygen. The luminophore is immobilized in plasticisized PVC and fixed to the fibre tip. When this dye is illuminated with a given wavelength, fluorescence is emitted; the intensity and lifetime is a function of the oxygen concentration (for details see Klimant et al., 1995, 1997a; Holst et al., 1997b, 2000). In addition to their long-term stability, optodes have the advantage not to consume the analyte and therefore exhibit no stirring sensitivity. They are also much easier to manufacture than oxygen electrodes.

Recently, oxygen optodes have been adapted and placed on benthic lander systems, making these sensors available for in situ studies of benthic mineralization processes with profilers and chambers (Glud et al., 1999a). Placing the fibre into a robust steel casing also allows the construction of long sensors for measuring the oxygen penetration in oligotrophic deep sea sediments, where penetration depths of several centimeters can be expected (Wenzhöfer et al., 2001a).

The introduction of $\mathrm{O}_{2}$ microelectrodes and microoptodes to sediment systems has allowed benthic $\mathrm{O}_{2}$ distribution to be studied with a very high temporal and spatial resolution (Revsbech and Jørgensen, 1986a,b; Klimant et al., 1995), which has subsequently increased our understanding of $\mathrm{O}_{2}$ dynamics in different benthic communities, and 
has provided new insights into the study of benthic microbial ecology. The benthic interface, however, is highly active, and intense production and degradation of organic carbon takes place within a narrow zone leading to a dynamic exchange of solutes between the benthic community and the overlying water. In addition, the interface is not a flat horizon but is typically characterized by extensive spatio-temporal heterogeneity, both at micro- and macro-scales. The recent introduction of planar optodes to the study of aquatic biology allows for two-dimensional quantification of the distribution and exchange of oxygen in marine sediments (Glud et al., 1996a,b, 1999b; Fenchel and Glud, 2000). These measurements quantify the spatial and temporal variability of oxygen at heterogeneous benthic interfaces with a spatial resolution of $<0.1 \mathrm{~mm}$ over areas of several square centimeters and at temporal resolutions of a few seconds (see Koenig et al., 2001 for a brief review). In addition, oxygen images provide a tool for the investigation of the direct coupling of small-scale biogeochemical processes, such as the tight coupling between autotrophic and heterotrophic microorganisms in a microbial mat (Glud et al., 1999b). In contrast to optical microsensors, where the fluorophore is tip-coated, a support foil is coated with the immobilized dye in these planar sensors. The planar optodes can then be used without insulation (so-called transparent optodes, see Holst and Grunwald, 2001) or they can be covered with a thin silicone layer to avoid illumination of the sediment (Glud et al., 1996a,b). The use of transparent planar oxygen optodes offers the advantage of combining 2D oxygen distribution images with simultaneously recorded sediment structure images (Holst and Grunwald, 2001) which allows for a direct correlation of areas with high or low activity (as determined from the oxygen images) with the matrix structure.

Recently, the planar optode technique was also incorporated onto benthic landers for in situ two-dimensional mapping of oxygen distribution in coastal sediments (Glud et al., 2001). They can also be left in place to study the temporal variation of chemical species associated with burrow creation and evolution, photosynthesis, and development of microzones. However, one should avoid using planar sensors for DBL studies in active areas where DBL impedance is significant. Since measurements are performed along a wall, the DBL is completely distorted, and does not represent natural conditions. At this stage, planar optodes can still be utilized for exchange or heterogeneity studies, but chemical gradient in the DBL should not be used to calculate field-derived flux. Laboratory investigations of early diagenesis in marine sediments with two-dimensional $\mathrm{pH}$ fluorosensors have also provided insight into how burrows, tubes and fecal structures influence the micro-environmental patterns of mineralization processes and these $\mathrm{pH}$-planar-optodes should be easily adapted to in situ devices (Hulth et al., 2002).

Because of their ability to address spatio-temporal variability in sediment systems, twodimensional optodes have the potential to help bridge the gap between the small-scale, highly site-specific microsensors measurements, and results from benthic chamber incubations, which integrate much larger areas.

\subsection{Gel probes and other in situ sampling techniques}

For certain analytes, in situ measurements using microelectrodes have not yet been developed. Polyacrylamide gel probes thus allow the sampling of pore waters at high resolution $(0.1$ to $1 \mathrm{~mm})$ with minimal disruption of the sediment-water interface, for 
subsequent laboratory analysis. Two gel probe methods have been developed: diffusional equilibration in thin-films (DET) and diffusive gradients in thin-films (DGT). Both methods include polyacrylamide gel, which consists of $>90 \%$ water and is typically $<1$ mm thick (Davison et al., 1994). The DET method is similar to dialysis methods (e.g., Hesslein, 1976), except that the thin gel sections allow for faster equilibration times relative to dialysis methods (24-48 h for DET probes compared to days or weeks for dialysis probes; Harper et al., 1997). The DGT method includes a thin film of gel containing a cation-exchange resin on the back of the polyacrylamide gel layer (Davison and Zhang, 1994), where ion species accumulate on the resin during the deployment time. Determining in situ element concentrations from DGT measurements can be complicated in pore waters due to species depletion near the gel surface during deployment and resupply from undefined phases (desorption from mineral or organic phases). However, there are a number of circumstances in which relative, qualitative or semi-quantitative information about a site can be useful. Because cation-exchange resins can concentrate analytes, DGT can be used to accumulate low-level species that might not otherwise be detectable, or to integrate analytes that might be variable with time (Zhang et al., 1995; Fones et al., 2001). It has also been suggested that DGT might provide a measure of the bioavailable or labile metal content (Hooda et al., 1999), though the correlation between DGT uptake and biological uptake has yet to be quantitatively determined.

DET probes can consist of a single long gel section or can have smaller gel sections constrained to openings $(0.4$ to $1 \mathrm{~mm})$ separated by thin dividers to eliminate profile relaxation after sampling (e.g., Fones et al., 1998; Mortimer et al., 1998). Gels made with low acrylamide monomer content coupled with bis-acrylamide as cross-linker have metal diffusion coefficients similar to diffusion through water and behave similarly to gels made with agarose-derivative cross-linker (Zhang and Davison, 1999), which is also commonly used (e.g., Fones et al., 1998). The probe face is covered with a membrane to physically protect the gel surface and prevent fouling from sediment particles. A PVC wedge attached to the back may increase the contact between the probe face and sediments and prevent vertical channeling of pore water (Morford et al., submitted for publication). After retrieval, unconstrained gel can be chemically fixed or quickly sectioned (DET) to prevent diffusional relaxation of the pore water profile or discrete gel sections can be removed (constrained DET). Individual gel sections are then back-equilibrated in dilute acid or water before analysis.

DET probes have been used to analyse alkalinity, $\mathrm{Cl}^{-}{ }_{(\mathrm{aq})}, \mathrm{NO}_{3}^{-}(\mathrm{aq}), \mathrm{SO}_{4}^{2-}$ (aq) $\mathrm{NH}_{4(\mathrm{aq})}^{+}$, $\mathrm{Ca}^{2+}{ }_{(\mathrm{aq})}, \mathrm{Mg}^{2+}{ }_{(\mathrm{aq})}, \mathrm{K}^{+}{ }_{(\mathrm{aq})}, \mathrm{Fe}^{2+}{ }_{(\mathrm{aq})}, \mathrm{Mn}^{2+}(\mathrm{aq}), \mathrm{U}_{(\mathrm{aq})}, \mathrm{Re}_{(\mathrm{aq})}$ and $\mathrm{Mo}_{(\mathrm{aq})}$ in both marine and lacustrine sediments (Morford et al., 2003, this volume; Fones et al., 1998, 2001; Shuttleworth et al., 1999; Zhang et al., 1999; Mortimer et al., 1998; Krom et al., 1994; Davison et al., 1991, 1994). The obtained sample volumes are often small using DET probes, so small sample volume analytical methods need to be developed and used (e.g., Hall and Aller, 1992). Davison et al. (2000) provide a thorough review of gel probe techniques and applications.

High resolution gel probe profiles allow for the calculation of fluxes across the sediment-water interface, where chemical gradients are typically steep, and show promise for advancing our knowledge of chemical processes. Results show sharp features in pore water profiles that would not have been observable when averaging over larger depth and 
time intervals (e.g., Fones et al., 2001; Shuttleworth et al., 1999; Zhang et al., 1995) and should thus improve our mechanistic understanding of element cycling with $\mathrm{Mn}$ and $\mathrm{Fe}$ phases. Measurement of horizontal concentration gradients, in addition to vertical gradients, further characterizes the heterogeneity within sediments, while providing a two-dimensional portrayal of the system (Shuttleworth et al., 1999). The coupling of an autonomous benthic lander with gel probes allows for in situ deployment of probes and expands the application of gel probes to deeper waters (Fones et al., 2001).

Despite of the recent success of gel probes, it is necessary to mention existing in situ pore waters filtration technique. In particular, the coupling of quasi-in situ whole core squeezing with a hollow sampler made of thick-walled aluminum tubing equipped with sampling ports (Martin and Sayles, 1996) allowed the extraction of pore waters for a limited number of analyses with millimeter-scale resolution, below $4000 \mathrm{~m}$ depths (Martin and Sayles, 1996).

\section{Emerging scientific issues and technologies}

There are countless important scientific and technical issues that lend themselves to investigation using in situ benthic biogeochemical assessment. While the increasing availability of these tools will lead research in yet unanticipated directions, a few emerging issues are listed here. They include greater insight into the controls on organic matter mineralization, improved models for the understanding of benthic fluxes to reconcile microelectrode and larger-scale chamber measurements, insight into the impacts of redox changes on trace metal behaviour, new insights into geochemical reaction pathways in surface sediments, and a better understanding of contaminant fate and behaviour in nearshore sediments.

\subsection{Organic matter recycling and burial}

Organic matter recycling and burial in marine sediments have been studied for many years. Nevertheless, fundamental questions remain which may now be addressed in greater detail with the use of in situ biogeochemical tools.

One important issue is how physical, chemical and biological factors control remineralization rates of organic matter in marine (or lacustrine) sediments (Canfield et al., 1993; Thamdrup and Canfield, 2000; Landen and Hall, 1998; Ståhl et al., in press (a,b); Aller et al., 1998). In particular, the study of the relative importance of the active biological community for degradation rates and pathways of organic matter (e.g., Piepenburg et al., 1995 ) is crucial to a full quantitative understanding. Here, the recent introduction of stable isotope techniques to the field is very promising (Levin et al., 1997, 1999; Middelburg et al., 2000 ), and the use of ${ }^{13} \mathrm{C} /{ }^{15} \mathrm{~N}$ labelled organic substrates in benthic chambers has allowed for the first detailed analysis of benthic degradation pathways in continental slope and deepsea sediments (Moodley et al., in press). The in situ application of these techniques is a very valuable tool for experimentally addressing questions like the relative importance of the various POC degradation pathways (e.g., oxic vs. anoxic), the relationship between the origin and reactivity of settling organic material and the corresponding degradation rates 
and pathways, and the role of terrigeneous material for the above named processes. A typical example relates to the importance of terrestrial material in the organic matter fraction being buried in continental margin sediments. De Haas et al. (2002) investigated burial of organic carbon in a great number of continental margin sediments off Europe and North and South America. They found that when burial was important in the shelf sediments they studied, the organic carbon being buried was mostly of terrestrial origin.

Another important issue is the role of DOC and DON fluxes in benthic carbon and nitrogen recycling (Hall et al., 1990; Skoog et al., 1996; Hulth et al., 1997; Burdige and Zheng, 1998; Alperin et al., 1999; Burdige et al., 1999; Landén and Hall, 2000; Burdige, 2001; Holcombe et al., 2001; Ståhl et al., in press (a,b)). Most studies published so far suggest that DOC fluxes are relatively small (in the order of $10-20 \%$ ) compared to corresponding DIC fluxes (or organic carbon oxidation rates). However, benthic DOC and DON fluxes could shed light on to the differences in carbon and nitrogen remineralization rates observed between coastal, shelf, slope and deep-sea sediments, and may help elucidate long time-scale changes and trends (Smith and Kauffmann, 1999; Smith et al., 2001).

\subsection{Sandy shelf sediments}

Until very recently most investigations have been constricted to muddy (relatively impermeable) sediments while sandy sediments, the prevailing sediment type of continental shelf regions, have been left largely unstudied (Boudreau et al., 2001; Huettel and Webster, 2001). This was primarily due to the common belief that sandy sediments are largely inactive due to their low organic content. This traditional view has now given way to a new paradigm which regards sands as biocatalytical filters with the ability to process organic matter at high rates. It is well known that the shelf seas are highly productive (Jørgensen, 1996; Walsh, 1988). There is thus a need to assess the contribution of shelf sediments to the remineralization of the organic matter produced within that area and to integrate this information into budgets of global carbon turnover. Another important subject for investigation is the cycling and fate of nutrients and contaminants, particularly since coastal and shelf areas are generally subject to high loading of these substances. As many traditional methods might not be reliable or appropriate to sands, future work must focus on methodological developments for sampling, in situ measurements and modelling, as well as large scale investigations in various shelf regions.

\subsection{Oxygen and carbon cycles in sediments}

Among organic matter degradation pathways, aerobic mineralization is generally considered to be of primary importance (although anaerobic pathways may play a major role in coastal sediments). Oxygen is used by aerobic microorganisms to directly oxidize organic matter or it is used to chemically or microbially oxidize reduced products (i.e., $\mathrm{NH}_{4}^{+}, \mathrm{Fe}^{2+}, \mathrm{Mn}^{2+}, \mathrm{H}_{2} \mathrm{~S}, \mathrm{CH}_{4}$ ) from the oxidation of organic matter (OM) by other electron acceptors. The determination of oxygen distribution allows one to extract kinetic parameters for reactions linked to oxygen consumption/production (such as organic matter mineralization, oxidation of reduced dissolved products, and photosynthesis by benthic microphytes). A proper approach to calculate a diffusive oxygen flux from a concentration 
profile is still in question, and should be standardized. Microprofile measurements always capture the oxygen gradients in the diffusive boundary layer (DBL) and, if resolution is high enough, one can calculate the flux from this gradient. However, the DBL is disturbed by the electrode itself (Glud et al., 1994a,b) and the accurate determination of the location of the sediment-water interface is sometime subjective, yet crucial for flux calculations. In order to define the optimal way to estimate fluxes from micro-electrode measurements, chamber experiments and microelectrode measurements have been made with homogenized sediments and in the absence of infauna, to compare different estimations of the oxygen flux (Tenberg et al., submitted for publication-a). Incubation experiment fluxes were used as the "real" oxygen flux to which different model calculations based on the observed microprofiles were compared: Berg's model (Berg et al., 1998) resulted in a good agreement between calculated and chamber fluxes, while other models (Bouldin, 1968; Cai and Sayles, 1996) resulted in calculated fluxes 1.5 to 2 times larger than Berg's model. The prevalence of the Berg model compared to the others is probably linked to the fact that it takes into consideration the multi-layered production/consumption zones in the sediment.

Moreover, one problem when calculating oxygen fluxes from microelectrode profiles is the lack of information on diffusivity on the same spatial scale $(100 \mu \mathrm{m})$. One solution proposed is the direct measurement of diffusivity using new sensors based on diffusion of gases from an electrode (Revsbech et al., 1998). These are able to determine diffusivity on retrieved cores at the appropriate depth scale (100 $\mu \mathrm{m}$, Elberling and Damgaard, 2001). Other techniques for measuring the water content are now being developed. For example, although not yet at the in situ stage, the use of nuclear magnetic resonance (NMR) could prove to be a useful tool for studying water content of the sediment (Wieland et al., 2001). Clearly, though, a more thorough evaluation of this important issue is required.

In sediment with intense biogeochemical activity, the paradigm of oxygen as the ultimate oxidant of the organic matter may be inappropriate and oxygen fluxes may not be converted into accurate organic matter remineralization rates because: (1) sediment heterogeneities due to bioirrigation preclude the use of one-dimensional porewater profiles to calculate rates of organic matter remineralization; (2) the precipitation of reduced metabolites (e.g., $\mathrm{FeS}, \mathrm{FeS}_{2}, \mathrm{MnCO}_{3}, \mathrm{FeCO}_{3}$ ) is not accounted for in converted oxygen diffusive fluxes; (3) some of the reduced metabolites may escape reoxidation by oxygen (e.g., $\mathrm{N}_{2}, \mathrm{NH}_{4}^{+}, \mathrm{Mn}^{2+}, \mathrm{CH}_{4}$ ); (4) the oxidation state of organic carbon (greater than zero) affects the $\mathrm{C} / \mathrm{N}$ ratio in reactions stoichiometry used to calculate organic matter remineralization rates. These issues could be addressed by coupling in situ microprofiles and benthic fluxes of each terminal electron acceptor and reduced metabolite with a diagenetic modeling approach that accounts for physical mixing and bioturbation to calculate the effect of sediment diagenesis on organic carbon preservation. Such an approach is not straightforward and will require intense collaborations between researchers from different fields and with a range of expertise.

\subsection{Trace elements and "new biogeochemical pathways"}

Narrow gaps between chemical profiles (e.g., between dissolved oxygen and dissolved iron profiles or between dissolved uranium and dissolved sulfide) can be used to examine 
whether reactions are coupled or decoupled, possibly providing insight into alternative reductants or oxidants (e.g., reactions between ammonium and manganese oxides or between ammonium and nitrate; Thamdrup and Dalsgaard, 2002). As a result of such finescale analyses, new secondary biogeochemical pathways, which would not have been apparent in traditional, lower-resolution porewater profiles, are now being proposed or identified. As with carbon cycling, there is a need to quantify how these new reactions are controlling or being influenced by (in the case of trace elements) long-term and seasonal changes, bioturbation and other perturbations. A major drawback of current technology, however, is the difficulty in determining the difference between time variations, spatial heterogeneity and manipulation artefacts. Therefore, ex situ kinetic experiments should be used to complement in situ studies (Roychoudhury et al., 1998). These could help to interpret in situ observations, to differentiate between biologically mediated and purely chemical reactions, and to reveal the production of transient/side species.

Technically, in situ determinations of trace elements or manganese and iron usually do not measure total dissolved concentrations, but rather corresponds to operationally defined speciation (e.g., "electroactive" species, "diffusive/mobile" species). Electrochemistry provides a way to address these issues and new methods continue to emerge in the literature. With improvements in nanotechnology, electrodes are likely to become smaller and more sensitive. In addition, with the recent progress in separation technology (e.g., DGT, DET), future studies will probably aim toward determining the chemical speciation of metals (i.e., organic and inorganic metal complexes, "free" metal) in situ by encasing microelectrodes into DGT- or DET-type membranes. Other electrochemical techniques, such as chronopotentiometry (i.e., potential stripping analysis or constantcurrent stripping analysis) and amperometry are gaining interest and may emerge as extremely useful techniques to analyse trace compounds. Finally, microsensors that can reach deeper depths and assess the effects of bioturbation/bioirrigation must be developed for more analytes. These processes are extremely important as they can shuttle carbon and trace elements through the oxic and suboxic zones, without chemical signature alteration.

\subsection{Contaminant fate and environmental management}

These emerging techniques can be applied to coastal management investigations (Apitz and Chadwick, 1999; Apitz et al., 2002). For instance, groundwater advective flow can provide a continuous or pulsed source of oxygen and nutrients to sediments and the water column (Moore, 1999), which may affect contaminant fate and transport, and thus, management strategies. Sediment biogeochemical responses to such events can result in either short- or long-term changes that need to be studied by in situ approaches, both to gain a fundamental understanding of how these processes affect chemical behavior and for environmental management. In fact, a number of dynamic pathways may contribute to contaminant transport and exposure at contaminated sediment sites. These include the effects of bed transport, bioturbation, diffusion and advection, resuspension and deposition, and transformation and degradation. The relative rates of these processes help define the potential risk of in-place contaminated sediments, pathways of exposure that must be controlled and, potentially, mechanisms of natural recovery of the sediment. An under- 
standing of the relative importance of these processes will focus site conceptual models and help risk managers balance these processes to minimize risk and, ideally, optimize recovery (Apitz and Chadwick, 1999). Such an evaluation should provide sufficient information to support decisions about which sediments can responsibly be managed in place, how aggressively they should be monitored or contained, or whether they should be removed and managed ex situ. Landers, microelectrodes, and newly refined seep meters will provide insight into the processes that drive contaminant fate and behavior in nearshore sediments (Chadwick et al., 2000; Paulsen et al., in press).

\subsection{Scaling issues}

The issues of scaling are non-trivial when one moves from small-scale microelectrode measurements $(0.1$ to $1 \mathrm{~mm})$ necessary for elucidating the mechanisms of biogeochemical processes to the larger-scale models and interpretation necessary to understand regional processes and extract global budgets. Our present view of spatial and temporal variability of biogeochemical processes, and how they respond to changes in climate, environment, or when one moves from coastal sediments to abyssal plains, is largely incomplete. Careful studies to reconcile microprofiles and chamber results have begun; insight from 2D optodes will aid in this conceptual link, as will higher-resolution studies. Commercially available in situ instrumentation has been placed on remotely operated vehicles (ROVs) and benthic landers to monitor biogeochemical processes in the environment over a variety of spatial and/or temporal scales. Expanding the number of multi-dimensional in situ investigations in heterogeneous sediment and including investigations through seasonal, tidal and other temporal cycles will provide practical insight into the large-scale variability of these processes.

\section{Guidelines for the future}

The new technologies that have emerged in the last decade (electrochemical, optical and gel probes) now require standardization and validation. Further scientific achievements will also likely arise from combined technologies and from new modeling approaches. Future benthic exploration may also benefit from concepts developed from current research in the medical, military, space and oil industries (i.e., international submarine laboratory, holochem probes, furtive benthic chambers and landers, single use benthic probes for time series chemical records, medical imagery and remote micromanipulators). These developments should help to miniaturize main components and increase the efficient- to dead-weight ratio on landers and benthic ROVs, as well as help expand their general capabilities.

General features of 'dream tools' to make decisive progress in the field of sediment biogeochemistry and early diagenesis can be summarized as follows: such equipment should combine high resolution and sensitivity with the possibility of in situ manipulation and the determination of chemical speciation. Sensors that can provide time-series data acquisition will be necessary. A combination of such properties could be developed from the combination of in situ voltammetry and gel techniques (Tercier-Waeber et al., 2000). 
Alternatively, current planar optodes (two-dimensional) could benefit from the addition of a gel probe set on the opaque face. Other compounds than $\mathrm{O}_{2}$ and $\mathrm{pH}$ could be detected using optodes, such as $\Sigma \mathrm{CO}_{2}$ and $\mathrm{NO}_{3}^{-}$. These compounds could potentially be combined on a single optode that could then simultaneously measure multiple elements. In order to eliminate any "wall effects" inherent in such intrusive methods, new devices derived from the concept of holography (which could be called "holochem"), allowing measurements "far" from the implantation location, could be developed in the future. The collection of $2 \mathrm{D}$ pictures from optodes also requires the development of $2 \mathrm{D}$ models that can provide quantitative information about the dynamic nature of the biogeochemical processes at the sediment-water interface. Small-scale acoustic imaging could also provide 2D information on the structure of the interface and the porosity of the sediment.

"Intelligent" landers are needed for sediment-water interface detection and for the optimization of deployment times and resolutions. In general, landers are deployed with a preset program of operation, which is not necessarily optimal for profiling close to the sediment-water interface. In order to minimise ship time needed and to get the proper profile definition, automatic detection of the sediment-water interface, and real-time interpretation of first measurements to automatically redefine profiling parameters, are essential and will most likely be developed in the near future. Furthermore, "furtive" landers that have no impact on sediment fluid dynamics and which can move around the landing site to check on lateral heterogeneity would be a major improvement.

Scaling measurements for large areas is definitely another challenge for this discipline. High-resolution, and thus small spatial scale, measurements are the basis for estimating fluxes, but estimates for large areas are required to address environmental issues. Heterogeneity is very large in coastal waters and tools are required to scale for site-specific results. Acoustics could be one of these tools, since it can be measured at small $(\mathrm{cm})$ to regional $(\mathrm{km})$ scales, provided that one can relate the acoustic properties of some habitats to their oxygen demand and small-scale acoustic properties (Freitas et al., this volume).

The recent development of high temporal and spatial resolution data and 2D/3D information needs to be accompanied by the development of computational models that are capable of utilizing such data. Summaries of current modelling capabilities can be found in Soetaert et al. (1996) and Boudreau (2000). An example of the use of 2D information in modelling can be seen in François et al. (2001). Future models should, in turn, extract information that cannot be measured directly, such as fine-scale spatial variability in microbial reaction rates and temporal evolution of redox boundaries along biological structures. Heterogeneity is the rule, but in locations where physical transport processes are dominant, homogeneity can be assumed even at the current finest scale of in situ observation. Hopefully, these will be adequate tools to reconcile flux values derived from either benthic chambers, on board incubations or high-resolution concentration profiles.

\section{Epilogue}

Heisenberg lives. At every level, the tools we use to observe our world affect what we see. While this has been compellingly (and distressingly) demonstrated at the subatomic level, as one moves to ever more complex and multivariate systems, this fact is all the more 
true, but perhaps less likely to be explicitly addressed. As oceanographers seeking to understand the complex inner space of benthic dynamics, we seek to characterize, with relatively few samples, the biogeochemical controls on processes which are affected by countless variables, and are heterogeneous on every spatial and temporal scale, and to extrapolate these results to regional, global and historical levels. To achieve this, we bring a number of tools to the table, ranging from in situ measurements and field samples to laboratory experiments and models, seeking to strike a balance between realism and control.

The development of in situ benthic assessment tools has provided unprecedented insight into the distribution, flux and behaviour of a limited, but rapidly growing, number of constituents. However, it must be remembered that even the most carefully designed in situ tool can change the environment it is observing, and these potential changes must be taken into account in data interpretation. While, for example, benthic chambers can be designed to address some of these changes, such as flexible-walled chambers for the effects of pressure gradients and $\mathrm{O}_{2}$ diffusion to offset respiration, no chamber can address all potential issues, nor can any sensor meet all potential limitations. Furthermore, an in situ observation can only report on the parameters measurable by that system, and cannot necessarily determine what parameters control changes in the measured parameter, or even measure all potentially important parameters. Spatial and temporal scaling issues can also produce problems - a very detailed microprofile is only truly representative of the very spot it is measuring.

It is because of these and many more issues that our understanding of benthic processes will advance most rapidly when we creatively partner in situ measurements with broader field sampling, well-designed laboratory experiments, and frequently calibrated and validated models. Experiments and models, informed by field measurements, can help us determine, under much more controlled conditions, driving mechanisms and processes. These efforts should then aid in the site selection and field design for further in situ work, testing laboratory and model results and driving the next iteration of models and experiments. If one accepts this iterative/collaborative model of oceanographic investigation, rather than a competition between those who work in the field and the laboratory, our understanding of benthic processes will evolve at an ever-accelerating pace.

\section{Acknowledgements}

The manuscript has benefited from insightful comments of two anonymous reviewers. They substantially improved the document. The authors acknowledge the BD conference organizing committee for their dedication and to the chairpersons and sponsoring organizations.

SEA acknowledges support from the Strategic Environmental Research and Development Program (SERDP CU-1209). JLM was funded by the Cabot Marine Environmental Science Fund and the J. Seward Johnson Fund. CR and KD were funded by CEA and CNRS through LSCE and INSU/ATI EV was supported by CNRS/INSU through MICROBENT and ATI project. FW was supported by a European Community Marie Curie Fellowship (HPMF-CT-2000-00569). PH and AT were supported by the Swedish Research Council (VR). [RW] 


\section{References}

Aller, R., Hall, P., Rude, P., Aller, J., 1998. Biogeochemical heterogeneity and suboxic diagenesis in hemipelagic sediments of the Panama Basin. Deep-Sea Res. 45, 133-165.

Alperin, M.J., Martens, C.S., Albert, D.B., Suayah, I.B., Benninger, L.K., Blair, N.E., Jahnke, R.A., 1999. Benthic fluxes and porewater concentration profiles of dissolved organic carbon in sediments from the North Carolina continental slope. Geochim. Cosmochim. Acta 63, 427-448.

Anderson, L., Hall, P., Iverfeldt, Å., Rutgers van der Loeff, M., Sundby, B., Westerlund, S., 1986. Benthic respiration measured by total carbonate production. Limnol. Oceanogr. 31, 319-329.

Apitz, S.E., Chadwick, D.B., 1999. SERDP CU1209: Pathway Ranking for In-place Sediment Management (PRISM) (http://www.serdp.org/research/CU/CU-1209.pdf).

Apitz, S.E., Davis, J.W., Finkelstein, K., Hohreiter, D.L., Hoke, R., Jensen, R.H., Kirtay, V.J., Jersac, J., Mack, E.E., Magar, V., Moore, D., Reible, D., Stahl, R., 2002. Critical issues for contaminated sediment management, MESO-02-TM-01 (http://meso.spawar.navy.mil/docs/MESO-02-TM-01.pdf).

Archer, D., Devol, A., 1992. Benthic oxygen fluxes on the Washington shelf and slope: a comparison of in situ microelectrode and chamber flux measurements. Limnol. Oceanogr. 37, 614-629.

Archer, D., Emerson, S., Reimers, C., 1989. Dissolution of calcite in deep-sea sediments: pH and $\mathrm{O}_{2}$ microelectrode results. Geochim. Cosmochim. Acta 53, 2831-2845.

Balzer, W., 1978. Untersuchungen über Abbau organischer Materie und Nährstoff-Freisetzung am Boden der Kieler Bucht beim Übergang vom oxischen zum anoxischen Milieu. PhD dissertation thesis, University of Kiel. 129 pp.

Berelson, W.M., Hammond, D.E., Cutter, G.A., 1990. In situ measurements of calcium carbonate dissolution rates in deep-sea sediments. Geochim. Cosmochim. Acta 54, 3013-3020.

Berg, P., Risgaard-Petersen, N., Rysgaard, S., 1998. Interpretation of measured concentration profiles in sediment pore water. Limnol. Oceanogr. 43, 1500-1510.

Black, K.S., Paterson, D.M., 1997. Measurement of the erosion potential of cohesive marine sediments: a review of current in situ technology. J. Mar. Environ. Eng. 4, 43-83.

Black, K.S., Tollhurst, T.J., Paterson, D.M., submitted for publication. Muddy sediment erosion—new data from the field.

Boudreau, B.P., 2000. The mathematics of early diagenesis: from worms to waves. Rev. Geophys. 38, $389-416$.

Boudreau, B.P., et al., 2001. Permeable marine sediments: overturning an old paradigm. Eos 82, $133-136$.

Bouldin, D.R., 1968. Models for describing the diffusion of oxygen and other mobile constituents across the mud-water interface. J. Ecol. 56, 77-87.

Brendel, P.J., Luther III, G.W. 1995. Development of a gold amalgam voltammetric microelectrode for the determination of dissolved $\mathrm{Fe}, \mathrm{Mn}, \mathrm{O}_{2}$, and $\mathrm{S}(-\mathrm{II})$ in porewaters of marine and freshwater sediments. Environ. Sci. Technol. 29, 751-761.

Buchholtztenbrink, M.R., Gust, G., Chavis, D., 1989. Calibration and performance of a stirred benthic chamber. Deep-Sea Res., A, Oceanogr. Res. Pap. 36 (7), 1083-1101.

Buffle, J., Horvai, G., 2000. In Situ Monitoring of Aquatic Systems: Chemical Analysis and Speciation Wiley, Chichester, UK.

Bull, D.C., Taillefert, M., 2001. Seasonal and topographic variations in porewaters of a southeastern USA salt marsh as revealed by voltammetric profiling. Geochem. Trans. 13, 1-8.

Burdige, D.J., 2001. Dissolved organic matter in Chesapeake Bay sediment pore waters. Org. Geochem. 32, 487-505.

Burdige, D.J., Zheng, S., 1998. The biogeochemical cycling of dissolved organic nitrogen in estuarine sediments. Limnol. Oceanogr. 43, 1796-1813.

Burdige, D.J., Berelson, W.M., Coale, K.H., McManus, J., Johnson, K.S., 1999. Fluxes of dissolved organic carbon from California continental margin sediments. Geochim. Cosmochim. Acta 63, 1507-1515.

Cai, W.-J., Reimers, C.E., 1993. The development of $\mathrm{pH}$ and $\mathrm{pCO}_{2}$ microelectrodes for studying the carbonate chemistry of pore waters near the sediment-water interface. Limnol. Oceanogr. 38, 1762-1787.

Cai, W.J., Reimers, C.E., Shaw, T., 1995. Microelectrode study of organic carbon degradation and calcite dissolution at a California continental Rise site. Geochim. Cosmochim. Acta 59, 497-511.

Cai, W.J., Sayles, F.L., 1996. Oxygen penetration depths and fluxes in marine sediments. Mar. Chem. 52, $123-131$. 
Canfield, D., Jørgensen, B.B., Fossing, H., Glud, R., Gundersen, J., Ramsing, N., Thamdrup, B., Hansen, J., Nielsen, L., Hall, P., 1993. Pathways of organic carbon oxidation in three continental margin sediments. Mar. Geol. 113, 27-40.

Chadwick, D.B., Stanley, S.D., Lieberman, S.H., 1993. A benthic flux chamber for monitoring pollution exchange rates at the sediment-water interface MTS'93. Technology Requirements in the Nineties. Marine Technology Society Conference Proceedings, Long Beach, California. Marine Technology Society, Columbus, MD, USA, p. 11.

Chadwick, D.B., Stanley, S., Lieberman, S.H., 1994. Autonomous benthic lander for polluted bays and harbors. Sea Technol. 35 (10), 10-15.

Chadwick, D.B., Kito, M., Carlson, A., Harre, B., 2000. Coastal Contaminant Migration Monitoring-Technology Review. A Technical Report Naval Facilities Engineering Service Center, Port Hueneme, CA.

Ciceri, G., Maran, S., Martinotti, W., Queirazza, G., 1992. Geochemical cycling of heavy-metals in a marine coastal area-benthic flux determination from pore water profiles and in situ measurements using benthic chambers. Hydrobiologia 235, 501-517.

Damgaard, L.R., Revsbech, N.P., 1997. A microscale biosensor for methane containing methanotrophic bacteria and an internal oxygen reservoir. Anal. Chem. 69, 2262-2267.

Davison, W., Zhang, H., 1994. In situ speciation measurements of trace components in natural waters using thinfilm gels. Nature 367, 546-548.

Davison, W., Grime, G.W., Morgan, J.A.W., Clarke, K., 1991. Distribution of dissolved iron in sediment pore waters at submillimetre resolution. Nature 352, 323-325.

Davison, W., Zhang, H., Grime, G.W., 1994. Performance characteristics of gel probes used for measuring the chemistry of pore waters. Environ. Sci. Technol. 28, 1623-1632.

Davison, W., Fones, G.R., Harper, M.P., Teasdale, P., Zhang, H., 2000. Dialysis, DET and DGT: in situ diffusional techniques for studying water, sediments and soils. In: Buffle, J., Horvai, G. (Eds.), In Situ Monitoring of Aquatic Systems: Chemical Analysis and Speciation. Wiley, Chichester, New York, pp. 495-569.

De Beer, D., 1997. Microenvironments and mass transfer phenomena in biofilms and activated sludge studied with microsensors. In: Verachtert, H., Verstraete, W. (Eds.), Proceedings of the Int. Sym. on Environmental Biotechnology. Koninklijke Vlaamse Ingenieursverininging, Antwerpe, pp. 217-224.

De Beer, D., Glud, A., Epping, E., Kühl, M., 1997a. A fast-responding $\mathrm{CO}_{2}$ microelectrode for profiling sediments, microbial mats, and biofilms. Limnol. Oceanogr. 42, 1590-1600.

De Beer, D., Schramm, A., Santegoeds, C.M., Kühl, M., 1997b. A nitrite microsensor for profiling environmental biofilms. Appl. Environ. Microbiol. 63, 973-977.

De Haas, H., van Weering, T.C.E., de Stigter, H., 2002. Organic carbon in shelf seas: sinks or sources, processes and products. Cont. Shelf Res. 22, 691-717.

Drazen, J.C., Baldwin, R.J., Smith, K.L., 1998. Sediment community response to a temporally varying food supply at an abyssal station in the NE Pacific. Deep-Sea Res., Part 2, Top. Stud. Oceanogr. 45 (4-5), 893-913.

Elberling, B., Damgaard, L.R., 2001. Microscale measurements of oxygen diffusion and consumption in subaqueous sulfide tailings. Geochim. Cosmochim. Acta 65, 1897-1905.

Fenchel, T., Glud, R.N., 2000. Benthic primary production and $\mathrm{O}_{2}-\mathrm{CO}_{2}$ dynamics in a shallow-water sediment: spatial and temporal heterogeneity. Ophelia 53 (3), 159-171.

Florence, T.M., 1986. Electrochemical approaches to trace element speciation in waters: a review. Analyst 111, $489-505$.

Fones, G.R., Davison, W., Grime, G.W., 1998. Development of constrained DET for measurements of dissolved iron in surface sediments at sub-mm resolution. Sci. Total Environ. 221, 127-137.

Fones, G.R., Davison, W., Holby, O., Jorgensen, B.B., Thamdrup, B., 2001. High-resolution metal gradients measured by in situ DGT/DET deployment in Black Sea sediments using an autonomous benthic lander. Limnol. Oceanogr. 46 (4), 982-988.

François, F., Poggiale, J.C., Durbec, J.P., Stora, G., 2001. A new model of bioturbation for a functional approach to sediment reworking resulting from macrobenthic communities. In: Aller, J.Y., Woodin, S.A., Aller, R.C. (Eds.), Organism-Sediment Interactions. Belle W. Baruch Library in Marine Science, No. 21, Univ. of South Carolina Press, USA, pp. 73-86.

Glazer, B.T., Cary, S.C., Hohmann, L., Luther III, G.W., 2002. In situ sulfur speciation using Au/Hg microelectrodes as an aid to microbial characterization of an intertidal salt marsh microbial mat. In: Taillefert, M., 
Rozan, T.F. (Eds.), Environmental Electrochemistry: Analyses of Trace Element Biogeochemistry American Chemical Society Symposium Series 811, Washington, DC, pp. 283-304.

Glud, R.N., Blackburn, N., 2002. The effects of chamber size on benthic oxygen uptake measurements: a simulation study. Ophelia 56, 23-31.

Glud, R.N., Gundersen, J.K., Jørgensen, B.B., Revsbech, N.P., Schulz, H.D., 1994a. Diffusive and total oxygen uptake of deep-sea sediments in the eastern South Atlantic Ocean: in situ and laboratory measurements. DeepSea Res. 41, $1767-1788$.

Glud, R.N., Gundersen, J.K., Revsbech, N.P., Jorgensen, B.K., 1994b. Effects on benthic diffusive boundary layer imposed by microelectrodes. Limnol. Oceanogr. 39, 462-467.

Glud, R.N., Gundersen, J.K., Revsbech, N.P., Jorgensen, B.B., Huttel, M., 1995. Calibration and performance of the stirred flux chamber from the benthic lander elinor. Deep-Sea Res., Part 1, Oceanogr. Res. Pap. 42 (6), $1029-1042$.

Glud, R.N., Ramsing, N.B., Gundersen, J.K., Klimant, I., 1996a. Planar optrodes: a new tool for fine scale measurements of two-dimensional $\mathrm{O}_{2}$ distribution in benthic communities. Mar. Ecol., Prog. Ser. 140, $217-226$

Glud, R.N., Forster, S., Huettel, M., 1996b. Influence of radial pressure gradients on solute exchange in stirred benthic chambers. Mar. Ecol., Prog. Ser. 141, 303-311.

Glud, R.N., Klimant, I., Holst, G., Kohls, O., Meyer, V., Kühl, M., Gundersen, J.K., 1999a. Adaptation, test and in situ measurements with $\mathrm{O}_{2}$ microopt(r)odes on benthic landers. Deep-Sea Res., Part 1 46, $171-183$.

Glud, R.N., Kühl, M., Kohls, O., Ramsing, N.B., 1999b. Heterogeneity of oxygen production and consumption in a photosynthetic microbial mat as studied by planar optodes. J. Phycol. 35, 270-279.

Glud, R.N., Gundersen, J.K., Ramsing, N.B., 2000. Electrochemical and optical microsensors for in situ measurements. In: Buffle, J., Horvai, G. (Eds.), In situ Monitoring of Aquatic Systems-Chemical Analysis and Speciation. Wiley, Chichester, pp. 19-73.

Glud, R.N., Tengberg, A., Kühl, M., Hall, P.O.J., Klimant, I., 2001. An in situ instrument for planar $\mathrm{O}_{2}$ optode measurements at benthic interfaces. Limnol. Oceanogr. 46, 2073-2080.

Gnaiger, E., Forstner, H., 1983. Polarographic Oxygen Sensors: Aquatic and Physiological Applications Springer-Verlag, New York, NY 370 pp.

Gundersen, J.K., Jorgensen, B.B., 1990. Microstructure of diffusive boundary layers and to oxygen uptake of the sea floor. Nature 345, 604-607.

Hales, B., Emerson, S., 1996. Calcite dissolution in sediments of the Ontong-Java Plateau: in situ measurements of pore water $\mathrm{O}_{2}$ and $\mathrm{pH}$. Glob. Biogeochem. Cycles 10, 527-541.

Hales, B., Burgess, L., Emerson, S., 1997. An absorbance-based fiber-optic sensor for $\mathrm{CO}_{2}(\mathrm{aq})$ measurement in porewater of sea floor sediments. Mar. Chem. 59, 51-62.

Hall, P.O.J., 1984. Chemical fluxes at the sediment-seawater interface: in-situ investigations with benthic chambers. PhD dissertation thesis, University of Göteborg, Sweden, Göteborg. 183 pp.

Hall, P., Aller, R., 1992. Rapid, small-volume, flow injection analysis for $\mathrm{CO}_{2}$ and $\mathrm{NH}_{4}^{+}$in marine and freshwaters. Limnol. Oceanogr. 37, 1113-1119.

Hall, P., Anderson, L., Rutgers van der Loeff, M., Sundby, B., Westerlund, S., 1989. Oxygen uptake kinetics in the benthic boundary layer. Limnol. Oceanogr. 34, 734-746.

Hall, P., Anderson, L., Holby, O., Kollberg, S., Samuelsson, M.-O., 1990. Chemical fluxes and mass balances in a marine fish cage farm: I. Carbon. Mar. Ecol., Prog. Ser. 61, 61-73.

Hallberg, R.O., Bagander, L.E., Engvall, E.-G., Shippel, F.A., 1972. Method for studying geochemistry of sediment-water interface. Ambio 1, 71-72.

Hammond, D.E., Simpson, H.J., Mathieu, G., 1977. Radon-222 distribution and transport across the sedimentwater interface in the Hudson River estuary. J. Geophys. Res. 82, 3913-3920.

Harper, M.P., Davison, W., Tych, W., 1997. Temporal, spatial and resolution constraints for in situ sampling devices using diffusional equilibration: dialysis and DET. Environ. Sci. Technol. 31, 3110-3119.

Helder, W., Bakker, J.F., 1985. Shipboard comparison of microelectrode and mini electrodes for measuring oxygen distribution in marine sediments. Limonol. Oceanogr. 30, 1160-1169.

Hesslein, R.H., 1976. An in situ sampler for close interval pore water studies. Limnol. Oceanogr. 21 (6), $912-914$.

Holcombe, B.L., Kiel, R.G., Devol, A.H., 2001. Determination of pore-water dissolved organic carbon fluxes from Mexican margin sediments. Limnol. Oceanogr. 46, 298-308. 
Holst, G., Grunwald, B., 2001. Luminescence lifetime imaging with transparent oxygen optodes. Sens. Actuators, B 74, 78-90.

Holst, G., Mizaikoff, B., 2002. Fiber optic sensors for environmental applications. In: Lopez-Higuera, J.M. (Ed.), Handbook of Optical Fibre Sensing Technology. Wiley, Chichester, UK, pp. 729-755.

Holst, G., Kühl, M., Klimant, I., Liebsch, G., Kohls, O., 1997a. Characterization and application of temperature microoptodes for use in aquatic biology. SPIE Proc. 2980, 164-171.

Holst, G., Glud, R.N., Kühl, M., Klimant, I., 1997b. A microoptode array for fine-scale measurement of the oxygen distribution. Sens. Actuators, B 38-39, 122-129.

Holst, G., Klimant, I., Kühl, M., Kohls, O., 2000. Optical microsensors and microprobes. In: Varney, M.S. (Ed.), Chemical Sensors in Oceanography. Gordon \& Breach, Amsterdam, pp. 143-188.

Hooda, P.S., Zhang, H., Davison, W., Edwards, A.C., 1999. Measuring bioavailable trace metals by diffusive gradients in thin films (DGT): soil moisture effects on its performance in soils. Eur. J. Soil Sci. 50, 285-294.

Huber, C., Klimant, I., Krause, C., Werner, T., Mayr, T., Wolfbeis, O.S., 2000. Optical sensor for seawater salinity. Fresenius' J. Anal. Chem. 368, 196-202.

Huber, C., Klimant, I., Krause, C., Werner, T., Wolfbeis, O.S., 2001a. Nitrate-selective optical sensor applying a lipophilic fluorescent potential-sensitive dye. Anal. Chim. Acta 449, 81-93.

Huber, C., Klimant, I., Krause, C., Wolfbeis, O.S., 2001b. Dual referencing (DLR) as applied to a chloride optical sensor. Anal. Chim. Acta 73, 2097-2103.

Huettel, M., Gust, G., 1992a. Impact of bioroughness on interfacial solute exchange in permeable sediments. Mar. Ecol., Prog. Ser. 89, 253-267.

Huettel, M., Gust, G., 1992b. Solute release mechanisms from confined sediment cores in stirred benthic chambers and flume flows. Mar. Ecol., Prog. Ser. 82 (2), 187-197.

Huettel, M., Rusch, A., 2000. Transport and degradation of phytoplankton in permeable sediment. Limnol. Oceanogr. 45 (3), 534-549.

Huettel, M., Webster, I.T., 2001. Porewater flow in permeable sediments. In: Boudreau, B.P., Jørgensen, B.B. (Eds.), The Benthic Boundary Layer: Transport Processes and Biogeochemistry. Oxford Univ. Press, New York, pp. 144-179.

Huettel, M., Ziebis, W., Forster, S., 1996. Flow-induced uptake of particulate matter in permeable sediments. Limnol. Oceanogr. 41 (2), 309-322.

Hulth, S., Blackburn, T.H., Hall, P.O.J., 1994. Arctic sediments (Svalbard): consumption and microdistribution of oxygen. Mar. Chem. 46, 293-316.

Hulth, S., Tengberg, A., Landén, A., Hall, P., 1997. Mineralization and burial of organic carbon in sediments of the southern Weddell Sea (Antarctica). Deep-Sea Res. 44, 955-981.

Hulth, S., Aller, R.C., Engström, P., Selander, E., 2002. A ph plate fluorosensor (optode) for early diagenetic studies of marine sediments. Limnol. Oceanogr. 47, 212-220.

Jahnke, R.A., 1990. Early diagenesis and recycling of biogenic debris at the seafloor, Santa Monica Basin, California. J. Mar. Res. 48, 413-436.

Jahnke, R.A., 1996. The global ocean flux of particulate organic carbon: areal distribution and magnitude. Glob. Biogeochem. Cycles 10 (1), $71-88$.

Jahnke, R.A., Craven, D.B., Gaillard, J.-F., 1994. The influence of organic matter diagenesis on CacO3 dissolution at the deep-sea floor. Geochim. Cosmochim. Acta 58, 2799-2809.

Jerochewski, P., Braun, S., 1996. A flow analysis system with an amperometric detector for the determination of hydrogen sulfide in waters. Fresenius' J. Anal. Chem. 354, 169-172.

Jørgensen, B.B., 1977. The sulphur cycle of a coastal marine sediment (Limfjorden, Denmark). Limnol. Oceanogr. $5,814-832$.

Jørgensen, B.B., 1996. Material flux in the sediment. In: Jørgensen, B.B., Richardson, K. (Eds.), Eutrophication in Coastal Marine Ecosystems. Coastal and Estuarine Studies. American Geophysical Union, Washington, pp. $115-135$.

Jørgensen, B.B., Boudreau, B.P., 2001. Diagenesis and sediment-water exchange. In: Boudreau, B.P., Jørgensen, B.B. (Eds.), The Benthic Boundary Layer. Transport Processes and Biogeochemistry. Oxford Univ. Press, UK, 404 pp.

Jørgensen, B.B., Des Marais, D.J., 1990. The diffusive boundary layer of sediments: oxygen microgradients over a microbial mat. Limnol. Oceanogr. 35, 1343-1355. 
Jørgensen, B.B., Revsbech, N.P., 1985. Diffusive boundary layers and the oxygen uptake of sediments and detritus. Limnol. Oceanogr. 30, 111-122.

Klimant, I., Meyer, V., Kühl, M., 1995. Fiber-optic oxygen micosensors, a new tool in aquatic biology. Limnol. Oceanogr. 40, 1159-1165.

Klimant, I., Kühl, M., Glud, R.N., Holst, G., 1997a. Optical measurement of oxygen and temperature in microscale: strategies and biological applications. Sens. Actuators, B 38-29, $29-37$.

Klimant, I., Holst, G., Kühl, M., 1997b. A simple fiber-optic sensor to detect the penetration of microsensors into sediments and other biogeochemical systems. Limnol. Oceanogr. 42, 1638-1643.

Koenig, B., Holst, G., Glud, R.N., Kühl, M., 2001. Imaging of oxygen distributions at benthic interfaces: a brief review. In: Aller, J.Y., Woodin, S.A., Aller, R.C. (Eds.), Organism-Sediment Interactions. University of South Carolina Press, Columbia, pp. 63-71.

Kohls, O., Klimant, I., Holst, G., kühl, M., 1997. Development and comparison of pH microoptodes for use in marine systems. SPIE Proc. 2978, 82-94.

Krom, M.D., Davison, P., Zhang, H., Davison, W., 1994. High-resolution pore-water sampling with a gel sampler. Limnol. Oceanogr. 39 (8), 1967-1972.

Kühl, M., Revsbech, N.P., 2001. Biogeochemical microsensors for boundary layer studies. In: Boudreau, B.P., Jørgensen, B.B. (Eds.), The Benthic Boundary Layer-Transport Processes and Biogeochemistry. Oxford Univ. Press, Oxford, pp. 180-210.

Kühl, M., Lassen, C., Jørgensen, B.B., 1994. Light penetration and light intensity in sandy marine sediments measured with irradiance and scalar irradiance fiber-optic mircroprobes. Mar. Ecol., Prog. Ser. 105, 139-148.

Kühl, M., Lassen, C., Revsbech, N.P., 1997. A simple light meter for measurements of PAR (400-700 nm) with fiber-optic microprobes: application for P vs. I measurements in microbenthic communities. Aquat. Microb. Ecol. 13, 197-207.

Kühl, M., Steuckart, C., Eickert, G., Jeroschewski, P., 1998. A $\mathrm{H}_{2} \mathrm{~S}$ microsensor for profiling biofilms and sediments: application in an acidic lake sediment. Aquat. Microb. Ecol. 15, 201-209.

Landén, A., Hall, P., 1998. Seasonal variation of dissolved and adsorbed amino acids and ammonium in a nearshore marine sediment. Mar. Ecol. Prog. Ser. 170, 67-84.

Landén, A., Hall, P., 2000. Benthic fluxes and porewater distributions of dissolved free amino acids in the open Skagerrak. Mar. Chem. 71, 53-68.

Larsen, L.H., Kjaer, T., Revsbech, N.P., 1997. A microscale $\mathrm{NO}_{3}^{-}$biosensor for environmental applications. Anal. Chem. 69, 3527-3531.

Lassen, C., Ploug, H., Jørgensen, B.B., 1992. A fibre-optic scalar irradiance microsensor: application for spectral light measurements in sediments. FEMS Microbiol. Ecol. 86, 247-254.

Leather, J.M., Chadwick, D.B., Koon, G., 1995. Contaminant flux measurements across the sediment-water interface in San Diego Bay. Proceedings of Oceans '95, vol. 3, 1700-1713.

Levin, L.A., Blair, N.E., DeMaster, D.J., Plaia, G., Fornes, W., Martin, C., Thomas, C., 1997. Rapid subduction of organic matter by maldanid polychaetes on the North Carolina slope. J. Mar. Res. 55, 595-611.

Levin, L.A., Blair, N.E., Martin, C.M., DeMaster, D.J., Plaia, G., Thomas, C.J., 1999. Macrofaunal processing of phytodetritus at two sites on the Carolina margin: in situ experiments using ${ }^{13} \mathrm{C}$-labeled diatoms. Mar. Ecol. Prog. Ser. 182, 37-54.

Luther, G.W.I., Sundby, B., Lewis, B.L., Brendel, P.J., Silverberg, N., 1997. Interactions of manganese with the nitrogen cycle: alternative pathways to dinitrogen. Geochim. Cosmochim. Acta 61, 4043-4052.

Luther III, G.W., Reimers, C.E., Nuzzio, D.B., Lovalvo, D., 1999. In situ deployment of voltammetric, potentiometric, and amperometric microelectrodes from a ROV to determine dissolved $\mathrm{O}_{2}, \mathrm{Mn}, \mathrm{Fe}, \mathrm{S}(-2)$, and $\mathrm{pH}$ in porewaters. Environ. Sci. Technol. 33, 4352-4356.

Luther III, G.W., Glazer, B.T., Hohmann, L., Popp, J.I., Taillefert, M., Rozan, T.F., Brendel, P.J., Theberge, S.M., Nuzzio, D.B. 2001. Sulfur speciation monitored in situ with solid state gold amalgam voltammetric microelectrodes: polysulfides as a special case in sediments, microbial mats, and hydrothermal vent waters. J. Environ. Monit. 3, 61-66.

Malan, D.E., Mc Lachlan, A., 1991. In situ benthic oxygen fluxes in a nearshore coastal marine system: a new approach to quantify the effect of wave action. Mar. Ecol. Prog. Ser. 73, 69-81.

Martin, W.R., Sayles, F.L., 1996. $\mathrm{CaCO}_{3}$ dissolution in sediments of the Ceara Rise, western equatorial Atlantic. Geochim. Cosmochim. Acta 60, 243-263. 
McCaffrey, R.J., Myers, A.C., Davey, E., Morrison, G., Bender, M., Luedtke, N., Cullen, D., Froelich, P., Klinkhammer, G., 1980. The relation between pore water chemistry and benthic fluxes of nutrients and manganese in Narragansett Bay, Rhode Island. Limnology and Oceanography 25, 31-44.

Meyer, R.L., Kjaer, T., Revsbech, N.P., 2001. Use of $\mathrm{NO}_{x}^{-}$microsensors to estimate the activity of sediment nitrification and $\mathrm{NO}_{x}^{-}$consumption along an estuarine salinity, nitrate, and light gradient. Aquat. Microb. Ecol. 26, $181-193$.

Middelburg, J.J., Barranguet, C., Boschker, H.T.S., Hermann, P.M.J., Moens, T., Heip, C.H.R., 2000. The fate of intertidal microphytobenthos carbon: an in situ ${ }^{13} \mathrm{C}$-labeling study. Limnol. Oceanogr. 45 (6), $1224-1234$.

Moodley, L., Middelburg, J.J., Boschker, H.T.S., Duineveld, G.C.A., Pel, R., Hermann, P.M.J., Heip, C.H.R., 2002. Bacteria and Foraminifera: key players in a short-term deep-sea benthic response to phytodetritus. Mar. Ecol. Prog. Ser. 236, 23-29.

Moore, W.S., 1999. The subterranean estuary: a reaction zone of ground water and sea water. Mar. Chem. 65, $111-125$.

Morford, J., Kalnejais, L., Martin, W., François, R., Karle, I.-M., 2003. Sampling marine pore waters for Mn, Fe, $\mathrm{U}, \mathrm{Re}$, and Mo: modifications on diffusional equilibration thin film gel probes. J. Exp. Mar. Biol. Ecol. 285286, 85-103 (this volume).

Mortimer, R.J.G., Krom, M.D., Hall, P.O.J., Hulth, S., Ståhl, H., 1998. Use of gel probes for the determination of high resolution solute distributions in marine and estuarine pore waters. Mar. Chem. 63, 119-129.

Müller, B., Buis, K., Stierli, R., Wehrli, B., 1998. High spatial resolution measurements in lake sediments with PVC based liquid membrane ion-selective electrodes. Limnol. Oceanogr. 43, 1728-1733.

Neurauter, G., Klimant, I., Wolfbeis, O.S., 2000. Fiber-optic microsensor for high resolution $p \mathrm{CO}_{2}$ sensing in marine environment. Fresenius' J. Anal. Chem. 366, 481-487.

Nixon, W.S., Oviatt, C.A., Hale, S.S., 1976. Nitrogen regeneration and the metabolism of coastal bottom communities. In: Anderson, J.M., Macfayden, A. (Eds.), The Role of Terrestrial and Aquatic Organisms in Decomposition Process. British Ecological Symposium Series, Blackwell Scientific, Oxford, pp. 269-283.

Nolan, M.A., Gaillard, J.-F., 2002. Probing zinc speciation in contaminated sediments by square wave voltammetry at a $\mathrm{Hg} / \mathrm{Ir}$ microelectrode. In: Taillefert, M., Rozan, T.F. (Eds.), Environmental Electrochemistry: Analyses of Trace Element Biogeochemistry, American Chemical Society, Symposium Series 811, Washington, DC, pp. 210-226.

Opdyke, B.N., Gust, G., Ledwell, J.R., 1987. Mass-transfer from smooth alabaster surfaces in turbulent flows. Geophys. Res. Lett. 14 (11), 1131-1134.

Paulsen, R.J., Smith, C.F., O'Rourke, D.E., Wong, T.-F., 2001. Development and evaluation of an ultrasonic groundwater seepage meter. J. Ground Water 39 (6), 904-911.

Pfannkuche, O., 1993. Benthic response to the sedimentation of particulate organic-matter at the biotrans station, 47-degrees-N, 20-degrees-W. Deep-Sea Res., Part 2, Top. Stud. Oceanogr. 40 (1-2), 135-149.

Piepenburg, D., Blackburn, T.H., von Dorrien, C., Gutt, J., Hall, P., Hulth, S., Kendall, M., Opalinski, K., Rachor, E., Schmid, M., 1995. Partitioning of benthic community respiration in the Arctic (northwestern Barents Sea). Mar. Ecol., Prog. Ser. 118, 199-213.

Rabouille, C., Denis, L., Dedieu, K., Stora, G., Lansard, B., Grenz, C., 2003. Oxygen demand in coastal marine sediments: comparing in situ microelectrodes and laboratory core incubations. J. Exp. Mar. Biol. Ecol. 285-286, 49-61 (this volume).

Reimers, C.E., Fischer, K.M., Merewether, R., Smith Jr., K.L., Jahnke, R.A. 1986. Oxygen microprofiles measured in situ in deep ocean sediments. Nature 320, 741-744.

Reimers, C.E., Jahnke, R.A., Thomsen, L., 2001. In situ sampling in the benthic boundary layer. In: Boudreau, B.B., Jørgensen, B.B. (Eds.), The Benthic Boundary Layer. Transport Processes and Biogeochemistry. Oxford Univ. Press, UK, 404 pp.

Revsbech, N.P., Jørgensen, B.B., 1986a. Microelectrodes: their use in microbial ecology. Adv. Microb. Ecol. 9, $293-303$.

Revsbech, N.P., Jorgensen, B.B., 1986b. Microelectrode studies of the photosynthesis and $\mathrm{O}_{2}, \mathrm{H}_{2} \mathrm{~S}$, and $\mathrm{pH}$ profiles of a microbial mat. Adv. Microbiol. Ecol. 9, 293-352.

Revsbech, N.P., Jorgensen, B.B., Blackburn, T.H., Cohen, Y., 1980. Oxygen in the seabottom measured with a microelectrode. Science 207, 1355-1356. 
Revsbech, N.P., Jørgensen, B.B., Blackburn, T.H., Cohen, Y., 1983. Limnol. Oceanogr. 28, 1062-1074.

Revsbech, N.P., Nielsen, L.P., Christensen, P.B., Sorensen, J., 1988. Combined oxygen and nitrous oxide microsensor for denitrification studies. J. Appl. Environ. Microbl. 54, 2245-2249.

Revsbech, N.P., Nielsen, L.P., Ramsing, N.B., 1998. A novel microsensor for determination of apparent diffusivity in sediments. Limnol. Oceanogr. 43, 986-992.

Rickard, D., Olroyd, A., Clamp, A., 1999. . Estuaries 22, 693-701.

Rowe, G.T., Boland, G.S., Phoel, W.C., Anderson, R.F., Biscaye, P.E., 1994. Deep-sea floor respiration as an indication of lateral input of biogenic detritus from continental margins. Deep-Sea Res., Part 2, Top. Stud. Oceanogr. $41(2-3), 657-668$.

Roychoudhury, A.N., Viollier, E., Van Cappellen, P., 1998. A plug flow-through reactor for studying biogeochemical reactions in undisturbed aquatic sediments. Appl. Geochem. 13, 269-280.

Rutgers van der Loeff, M.M., Anderson, L., Hall, P., Iverfeldt, Å., Josefson, A., Sundby, B., Westerlund, S., 1984. The asphyxiation technique - an approach to distinguishing between molecular-diffusion and biologically mediated transport at the sediment water interface. Limnol. Oceanogr. 29 (4), 675-686.

Santschi, P.H., Bower, P., Nyffeler, U.P., Azevedo, A., Broecker, W.S., 1983. Estimates of the resistance to chemical-transport posed by the deep-sea boundary-layer. Limnol. Oceanogr. 28 (5), 899-912.

Sayles, F.L., Martin, W.R., Deuser, W.G., 1994. Response of benthic oxygen-demand to particulate organiccarbon supply in the deep-sea near Bermuda. Nature 371 (6499), 686-689.

Shuttleworth, S.M., Davison, W., Hamilton-Taylor, J., 1999. Two-dimensional and fine structure in the concentrations of iron and manganese in sediment pore-waters. Environ. Sci. Technol. 33, 4169-4175.

Skoog, A., Hall, P., Hulth, S., Paxéus, N., Rutgers van der Loeff, M., Westerlund, S., 1996. Early diagenetic production and sediment-water exchange of fluorescent dissolved organic matter in the coastal environment. Geochim. Cosmochim. Acta 60, 3421-3431.

Smith, K.L., 1978. Benthic community respiration in NW Atlantic Ocean-in-situ measurements from 40 to 5200 m. Mar. Biol. 47 (4), 337-347.

Smith, K.L., Baldwin, R.J., 1984. Seasonal fluctuations in deep-sea sediment community oxygen-consumptionCentral and Eastern North Pacific. Nature 307 (5952), 624-626.

Smith, K.L., Kaufmann, R.S., 1999. Long-term discrepancy between food supply and demand in the deep eastern North Pacific. Science 284 (5417), 1174-1177.

Smith Jr., K.L., Baldwin, R.J., Williams, P.M., 1992. Reconciling particulate organic carbon flux and sediment community oxygen consumption in the deep North Pacific. Nature 359, 313-316.

Smith Jr., K.L., Glatts, R.C., Baldwin, R.J., Beaulieu, S.E., Uhlman, A.H., Horn, R.C., Reimers, C.E. 1997. An autonomous, bottom-transecting vehicle for making long time-series measurements of sediment community oxygen consumption to abyssal depths. Limnol. Oceanogr. 42 (7), 1601-1612.

Smith Jr., K.L., Kaufmann, S., Baldwin, R.J., Carlucci, A.F. 2001. Pelagic-benthic coupling in the abyssal eastern North Pacific: an 8-year time-series study of food supply and demand. Limnol. Oceanogr. 46, $543-556$.

Soetaert, K., Herman, P.M.J., Middelburg, J.J., 1996. A model of early diagenesis processes from the shelf to abyssal depths. Geochim. Cosmochim. Acta 60, 1019-1040.

Ståhl, H., Tengberg, A., Brunnegård, J., Hall, P., 2002a. Recycling and burial of organic carbon in sediments of the porcupine Abyssal Plain, NE Atlantic. Deep-Sea Res. (in press).

Ståhl, H., Tengberg, A., Brunnegård, J., Hall, P., Bjørnbom, E., Forbes, T., Josefson, A., Karle, I.-M., Olsgard, F., Roos, P., 2002b. Factors influencing organic carbon recycling and burial in Skagerrak sediments. J. Mar. Res. (in press).

Stueben, D., Koelbl, R., Haushahn, P., Schaupp, P., 1998. Measuring and sampling diffuse submarine hydrothermal vents. Int. Ocean Syst. Design 2, 6-12.

Taillefert, M., Luther III, G.W. 2000. The application of electrochemical tools for in-situ measurements in aquatic systems: a review. Electroanalysis 12, 401-412.

Taillefert, M., Rozan, T.F., 2002. Environmental Electrochemistry: Analyses of Trace Element Biogeochemistry. Oxford Univ. Press.

Taillefert, M., Bono, A.B., Luther III, G.W., 2000. Reactivity of freshly formed Fe(III) in synthetic solutions and (Pore) waters: voltammetric evidence of an aging process. Environ. Sci. Technol. 34, 2169-2177.

Taillefert, M., Rozan, T.F., Glazer, B.T., Herszage, J., Trouwborst, R.E., Luther Jr., G.W., 2002. Seasonal 
variations of soluble organic-Fe(III) in sediment porewaters as revealed by voltammetric microelectrodes. In: Taillefert, M., Rozan, T.F. (Eds.), Environmental Electrochemistry: Analyses of Trace Element Biogeochemistry, American Chemical Society Symposium Series 811, Washington DC, pp. 247-264.

Tengberg, A., de Bovée, F., Hall, P., Berelson, W., Chadwick, B., Ciceri, G., Crassous, P., Devol, A., Emerson, S., Gage, J., Glud, R., Graziottin, F., Gundersen, J., Hammond, D., Helder, W., Hinga, K., Holby, O., Jahnke, R., Khripounoff, A., Lieberman, H., Nuppenau, V., Pfannkuche, O., Reimers, C., Rowe, G., Sahami, A., Sayles, F., Schurter, M., Smallman, D., Wehrli, B., de Wilde, P., 1995. Benthic chamber and profiling landers in oceanography - a review of design, technical solutions and functioning. Prog. Oceanogr. 35, 253-294.

Tengberg, A., Almroth, E., Hall, P., 2003. Resuspension and its effects on organic carbon recycling and nutrient exchange in coastal sediments: in situ measurements using new experimental technology. J. Exp. Mar. Biol. Ecol. 285-286, 119-142 (this volume).

Tengberg, A., Hall, P., Andersson, U., Lindén, B., Styrenius, O., Boland, G., de Bovée, F., Carlsson, B., Ceradini, S., Devol, A., Duineveld, G., Friemann, J.-U., Glud, R., Khripounoff, A., Leather, J., Linke, P., Lund-Hansen, L., Rowe, G., Santschi, P., de Wilde, P., Witte, U., submitted for publication. Intercalibration of benthic flux chambers II. Hydrodynamic characterization and flux comparisons of 14 different designs. Marine Chemistry.

Tengberg, A., Ståhl, H., Gust, G., Hall, P., Müller, V., Arning, U., Andersson, H., submitted for publication. Intercalibration of benthic flux chambers: I. Accuracy of flux measurements and influence of chamber hydrodynamics. Prog. Oceanogr.

Tercier-Waeber, M.-L., Pei, J., Buffle, J., Fiaccabrino, G.C., Koudelka-Hep, M., Riccardi, G., Confalonieri, F., Sina, A., Graziottin, F., 2002. A novel voltammetric probe with individually addressable gel-integrated microsensor arrays for real-time high spatial resolution concentration profile measurements. Electroanalysis $12,27-34$.

Thamdrup, B., Canfield, D.E., 2000. Benthic respiration in aquatic sediments. In: Sala, O.E., Jackson, R.B., Mooney, H.A., Howarth, R.W. (Eds.), Methods in Ecosystem Science. Springer, New York, pp. 86-103.

Thamdrup, B., Dalsgaard, T., 2002. Production of N2 through anaerobic ammonium oxidation coupled to nitrate reduction in marine sediments. Appl. Environ. Microbiol. 68 (3), 1312-1318.

Theberge, S.M., Luther III, G.W., 1997. Determination of the electrochemical properties of a soluble aqueous FeS species present in sulfidic solutions. Aquat. Geochem. 3, 191-211.

Visscher, P.T., Beukema, J., van Gemerden, H., 1991. In situ characterization of sediments: measurements of oxygen and sulfides with a novel combined needle electrode. Limnol. Oceanogr., 1476-1480.

Visscher, P.T., Hoeft, S.E., Surgeon, T.-M.L., Rogers, D.R., Bebout, B.M., Thompson Jr., J.S., Reid, P., 2002. In: Taillefert, M., Rozan, T.F. (Eds.), Environmental Electrochemistry: Analyses of Trace Element Biogeochemistry, American Chemical Society Symposium Series 811, Washington, DC, pp. 265-282.

Walsh, J.J., 1988. On the Nature of Continental Shelves Academic Press, New York 520 pp.

Wenzhöfer, F., Glud, R.N., 2002. Benthic carbon mineralization in the Atlantic: a synthesis based on in situ data from the last decade. Deep-Sea Research Part I: Oceanographic Res. Papers 49 (7), 1255-1279.

Wenzhöfer, F., Holby, O., Glud, R.N., Nielsen, H.K., Gundersen, J.K., 2000. In situ microsensor studies of a shallow water hydrothermal vent at Milos, Greece. Mar. Chem. 69, 43-54.

Wenzhöfer, F., Holby, O., Kohls, O., 2001a. Deep penetrating benthic oxygen profiles measured in situ by oxygen optodes. Deep-Sea Res., Part 1 48, 1741-1755.

Wenzhöfer, F., Adler, M., Kohls, O., Hensen, C., Strotmann, B., Boehme, S., Schulz, H.D., 2001b. Calcite dissolution driven by benthic mineralization in the deep-sea: in situ measurements of $\mathrm{Ca}^{2+}, \mathrm{pH}^{2} p \mathrm{CO}_{2}$ and $\mathrm{O}_{2}$. Geochim. Cosmochim. Acta 65/16, 2677-2690.

Wieland, A., de Beer, D., Damgaard, L.R., Kuhl, M., van Dusschoten, D., Van As, H., 2001. Fine-scale measurements of diffusivity in a microbial mat with a nuclear magnetic resonance imaging. Limnol. Oceanogr. 46, $248-259$.

Witbaard, R., Duineveld, G.C.A, Van der Weele, J.A., Berghuis, E.M., Reyss, J.P., 2000. The benthic response to the seasonal deposition of phytopigments at the porcupine Abyssal Plain in the North East Atlantic. J. Sea Res. 43, 15-31.

Witte, U., Pfannkuche, O., 2000. High rates of benthic carbon remineralisation in the abyssal Arabian Sea. DeepSea Res., Part 2, Top. Stud. Oceanogr. 47 (14), 2785-2804. 
Witte, U., Aberle, N., Sand, M., Wenzhöfer, F., in press. Instantaneous response of a deep-sea benthic community to POM enrichment: in situ pulse chase experiments with ${ }^{13} \mathrm{C}$ labeled phytodetritus. Marine Ecology, Progress Series.

Witte, U., Aberle, N., Sand, M., Wenzhöfer, F., submitted for publication. Instantaneous response of a deep-sea benthic community to POM enrichment: in situ pulse chase experiments with ${ }^{13} \mathrm{C}$ labeled phytodetritus. Marine Ecology Progress Series.

Wolfbeis, O.S. (Ed.), 1991. Fiber Optic Sensors and Biosensors. CRC Press, New York.

Wolfbeis, O.S., 2000. Fiber-optic chemical sensors and biosensors. Anal. Chem. 72, 81R-89R.

Wolfbeis, O.S., Klimant, I., Werner, T., Huber, C., Kosch, U., Krause, C., Neurauter, G., Dürkop, A., 1998. Set of luminescence decay time based chemical sensors for clinical applications. Sens. Actuators, B 51, 17-34.

Xu, K., Dexter, S.C., Luther III, G.W., 1997. Corrosion 300, 1-18.

Zhang, H., Davison, W., 1999. Diffusional characteristics of hydrogels used in DGT and DET techniques. Anal. Chim. Acta 398, 329-340.

Zhang, H., Davison, W., Miller, S., Tych, W., 1995. In situ high resolution measurements of fluxes of $\mathrm{Ni}, \mathrm{Cu}, \mathrm{Fe}$ and $\mathrm{Mn}$ and concentrations of $\mathrm{Zn}$ and $\mathrm{Cd}$ in porewaters by DGT. Geochim. Cosmochim. Acta 59 (20), $4181-4192$.

Zhang, H., Davison, W., Ottley, C., 1999. Remobilisation of major ions in freshly deposited lacustrine sediment at overturn. Aquat. Sci. 61, 354-361.

Zhao, P.S., Cai, W.J., 1997. Anal. Chem. 69, 5052-5058. 